\title{
An In-Depth Look at Ground Source Heat Pumps and Other Electric Loads in Two GreenMax Homes
}

Srikanth Puttagunta and Carl Shapiro Consortium for Advanced Residential Buildings

April 2012 


\title{
This report received minimal editorial review at NREL
}

\begin{abstract}
NOTICE
This report was prepared as an account of work sponsored by an agency of the United States government. Neither the United States government nor any agency thereof, nor any of their employees, subcontractors, or affiliated partners makes any warranty, express or implied, or assumes any legal liability or responsibility for the accuracy, completeness, or usefulness of any information, apparatus, product, or process disclosed, or represents that its use would not infringe privately owned rights. Reference herein to any specific commercial product, process, or service by trade name, trademark, manufacturer, or otherwise does not necessarily constitute or imply its endorsement, recommendation, or favoring by the United States government or any agency thereof. The views and opinions of authors expressed herein do not necessarily state or reflect those of the United States government or any agency thereof.
\end{abstract}

Available electronically at http://www.osti.gov/bridge

Available for a processing fee to U.S. Department of Energy

and its contractors, in paper, from:

U.S. Department of Energy

Office of Scientific and Technical Information

P.O. Box 62

Oak Ridge, TN 37831-0062

phone: 865.576 .8401

fax: 865.576.5728

email: mailto:reports@adonis.osti.gov

Available for sale to the public, in paper, from:

U.S. Department of Commerce

National Technical Information Service

5285 Port Royal Road

Springfield, VA 22161

phone: 800.553 .6847

fax: 703.605.6900

email: orders@ntis.fedworld.gov

online ordering: http://www.ntis.gov/ordering.htm

Printed on paper containing at least $50 \%$ wastepaper, including $20 \%$ postconsumer waste 


\title{
An In-Depth Look at Ground Source Heat Pumps and Other Electric Loads in Two GreenMax Homes
}

\author{
Prepared for: \\ Building America \\ Building Technologies Program \\ Office of Energy Efficiency and Renewable Energy \\ U.S. Department of Energy \\ Prepared by: \\ Srikanth Puttagunta and Carl Shapiro \\ Steven Winter Associates, Inc. \\ of the \\ Consortium for Advanced Residential Buildings (CARB) \\ 61 Washington Street \\ Norwalk, CT 06854 \\ NREL Technical Monitor: Cheryn Engebrecht \\ Prepared under Subcontract No. KNDJ-0-40342-00
}

April 2012

iii 
[This page left blank] 


\section{Contents}

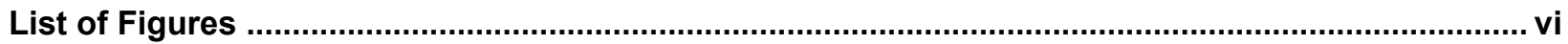

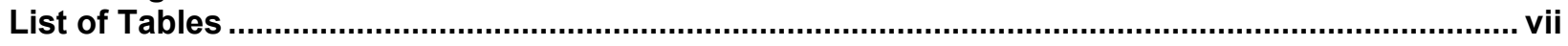

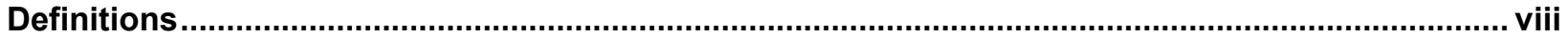

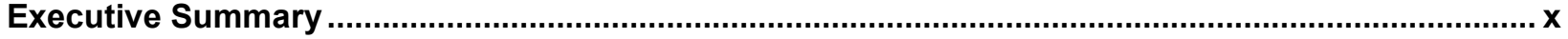

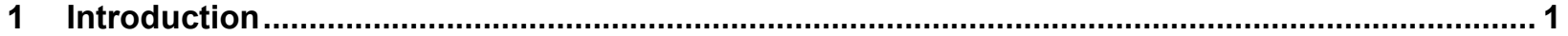

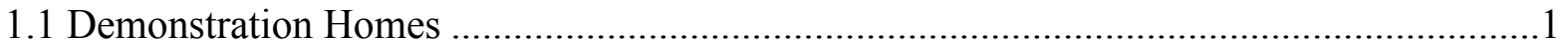

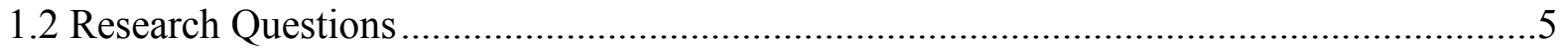

1.3 Expected Energy Savings Over Building America Benchmark ....................................5

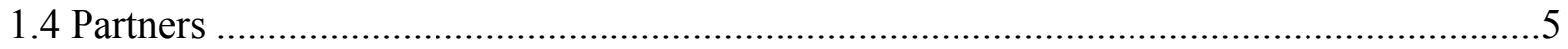

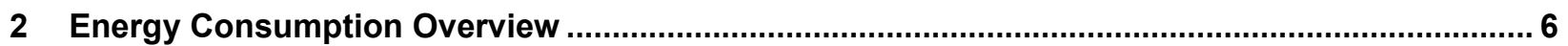

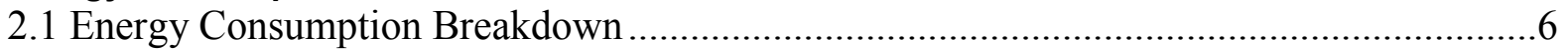

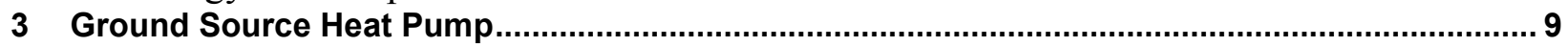

3.1 Ground Source Heat Pump Efficiency Metrics ....................................................... 10

3.1.1 Heating Coefficient of Performance ............................................................ 11

3.1.2 Domestic Hot Water Coefficient of Performance.................................................11

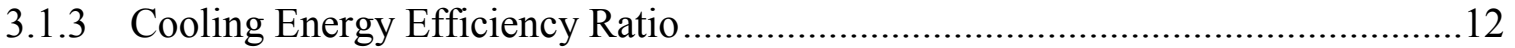

3.2 Ground Source Heat Pump Monitoring Results .................................................... 12

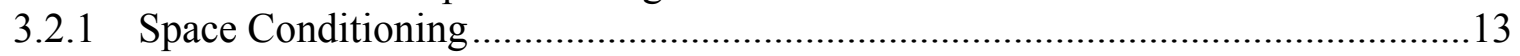

3.2.2 Ground Conditions...................................................................................... 16

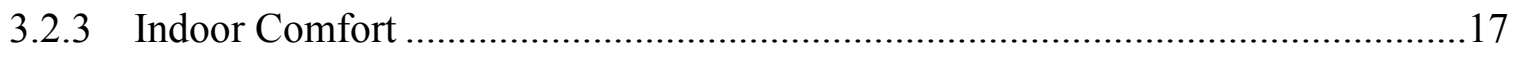

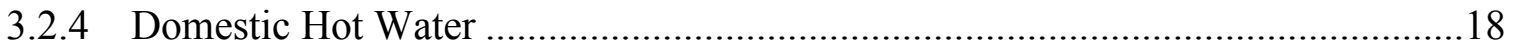

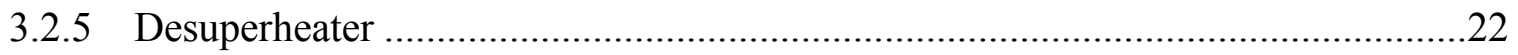

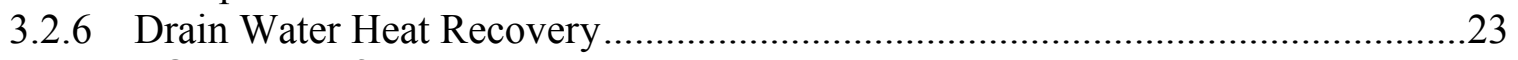

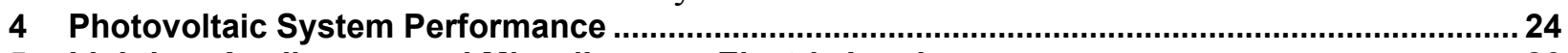

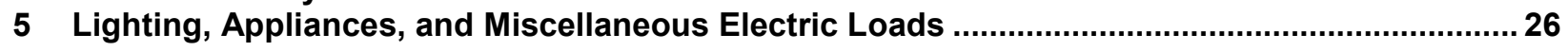

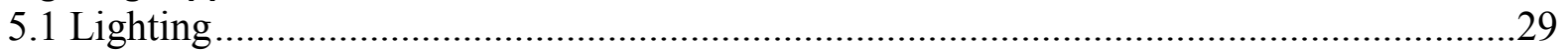

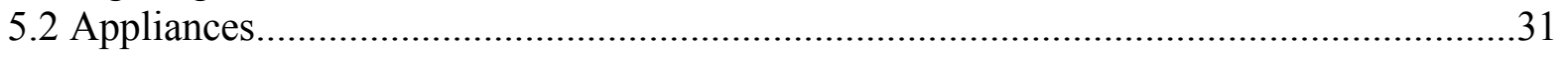

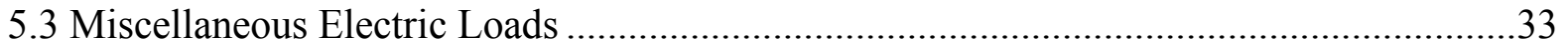

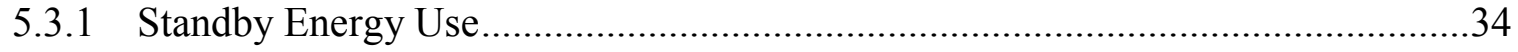

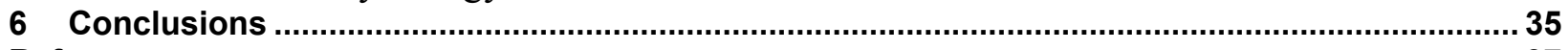

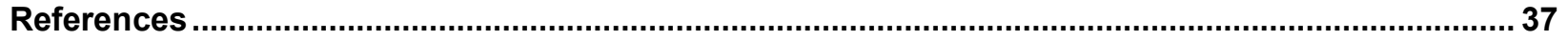




\section{List of Figures}

Figure 1. GreenMax home in Black River Falls, Wisconsin ......................................................... 2

Figure 2. GreenMax home in Stoughton, Wisconsin ..................................................................... 3

Figure 3. Site energy consumption by end use for Black River Falls home ...................................... 7

Figure 4. Site energy consumption by end use for Stoughton home .......................................... 7

Figure 5. Site energy consumption by end use for average home in Midwest - East North Central. 7 Figure 6. Mean monthly site energy component breakdown and generation of Black River Falls home

Figure 7. Mean monthly site energy component breakdown and generation of Stoughton home .... 8

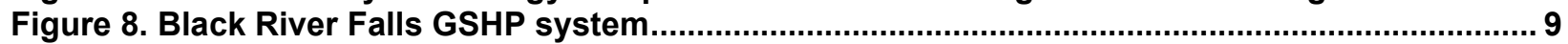

Figure 9 Installation of ground loop at Stoughton residence .......................................................... 10

Figure 10. Measured versus literature COP of Black River Falls GSHP for space heating............... 14

Figure 11. Measured versus literature EER of Black River Falls GSHP for space cooling ............... 14

Figure 12. Measured versus literature COP of Stoughton GSHP for space heating ....................... 15

Figure 13. Measured versus literature EER of Stoughton GSHP for space cooling ........................15

Figure 14. Mean daily ground temperature of the Stoughton home ground source field loop ........ 16

Figure 15. Buffer tank and storage tank in Stoughton home ......................................................... 19

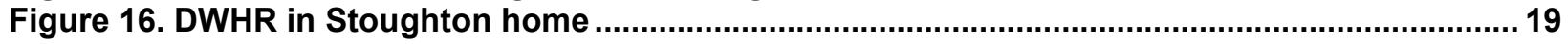

Figure 17. Schematic of GSHP/DHW systems at Black River Falls home ..................................... 19

Figure 18. Schematic of GSHP/DHW systems at Stoughton home .............................................. 20

Figure 19. Measured versus literature COP of Black River Falls GSHP DHW mode ........................ 21

Figure 20. Measured versus literature COP of Stoughton DHW GSHP ..........................................21

Figure 21. Water heating component breakdown for Black River Falls home in January ................ 22

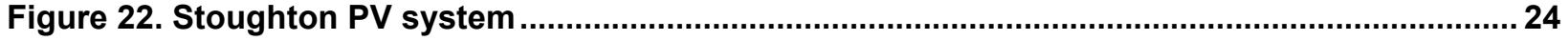

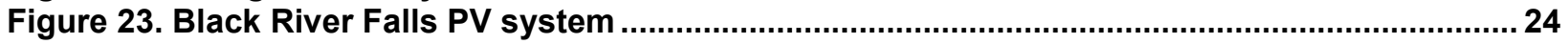

Figure 24. Black River Falls LAMEL breakdown (kWh/yr) ........................................................... 2

Figure 25. Stoughton LAMEL breakdown (kWh/yr) .................................................................. 28

Figure 26. Normalized hourly lighting profile comparison (Black River Falls) .................................. 30

Figure 27. Hourly normalized energy use profile comparison for major appliances.........................32

Figure 28. Monthly seasonal multipliers comparison for major appliances...................................... 32

Figure 29. Hourly normalized energy use profile comparison for MELs .........................................33

Figure 30. Monthly seasonal multipliers comparison for MELs ................................................... 34

Unless otherwise noted, all figures were created by CARB. 


\section{List of Tables}

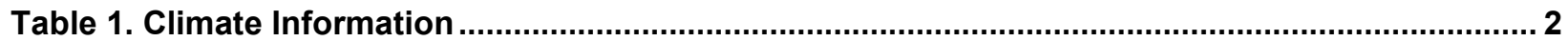

Table 2. Building Specifications for Test Homes ........................................................................... 4

Table 3. Source Energy Savings over BA B08 Benchmark ........................................................... 5

Table 4. Average Annual Energy Consumption and Generation by House ........................................ 6

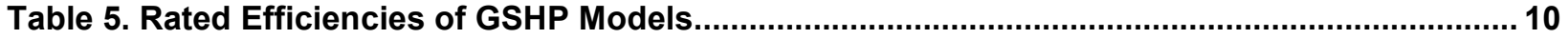

Table 6. Measured Efficiency of GSHPs ................................................................................... 12

Table 7. Rated Versus Measured System Efficiencies .................................................................. 13

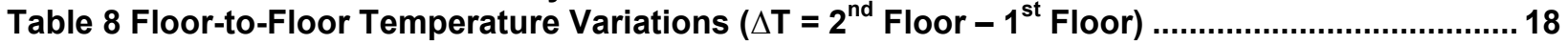

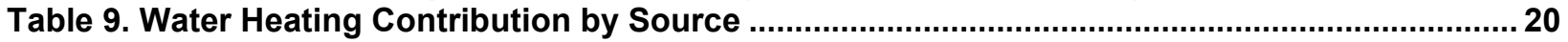

Table 10. PV System Performance Comparison to Modeled Values ............................................. 25

Table 11. Annual Lighting Electric Use Comparison at the Black River Falls Home (kWh/yr) ......... 29

Table 12. Yearly Major Appliance Electric Use Comparison (kWh/yr) ........................................... 31

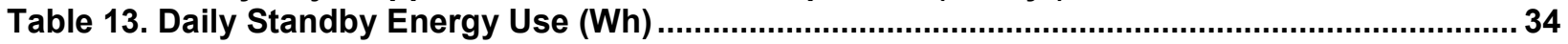

Unless otherwise noted, all tables were created by CARB. 


\section{Definitions}

$\mathrm{ACH}_{50} \quad$ Air changes per hour at a test pressure of 50 Pascal

$\mathrm{ACH}_{\text {natural }}$ Estimation of air changes per hour under natural operating conditions

ASHRAE American Society of Heating, Refrigerating and Air-Conditioning Engineers

BA Building America

BEopt Building Energy Optimization

Btu British thermal unit

CARB Consortium for Advanced Residential Buildings

CDD Cooling degree day

cfm Cubic feet per minute

$\operatorname{cfm}_{50} \quad$ Cubic feet per minute at a test pressure of 50 Pascal

COP Coefficient of performance

DHW Domestic hot water

DOE U.S. Department of Energy

DWHR Drain water heat recovery

EGUSA EnergyGauge USA

EER Energy efficiency ratio

ERV Energy recovery ventilator

FFA Finished floor area

FGB Fiberglass batt

gpm Gallons per minute

GSHP Ground source heat pump

HDD Heating degree day 
HSP House Simulation Protocol

HVAC Heating, ventilation, and air conditioning

ISO International Standards Organization

kWh Kilowatt-hour

LAMEL Lighting, appliances, and miscellaneous electric load

LED Light-emitting diode

MEL Miscellaneous electric load

NREL National Renewable Energy Laboratory

PV Photovoltaic

RECS Residential Energy Consumption Survey

SHGC Solar heat gain coefficient

W Watt

Wh Watt-hour 


\section{Executive Summary}

The U.S. Department of Energy's (DOE) Building America program continues to seek further confirmation of the true performance of homes and advanced mechanical systems through actual long-term field monitoring. Extensive monitoring of occupied homes provides valuable data that simply cannot be duplicated through laboratory tests and energy modeling.

Ground source heat pumps (GSHPs) are often touted as one of the most efficient, sustainable system choices for heating and cooling of homes. A DOE Energy Efficiency and Renewable Energy Web page, for example, claims that GSHPs have coefficients of performance (COPs) between 3.0 and 6.0 on winter design days:

Geothermal heat pumps (GHPs) use the constant temperature of the earth as the exchange medium instead of the outside air temperature. This allows the system to reach fairly high efficiencies (300\%-600\%) on the coldest of winter night (EERE 2011).

Although there is much anecdotal evidence, both supporting and detracting from GSHPs, few data document in-situ performance of GSHPs in homes. As a result of market penetration to date, the Building America Program has a limited number of monitored sites that provide documented performance data.

Similarly, there are few in-situ data about LAMELs (lighting, appliances, and miscellaneous electric loads) in residences. The TIAX U.S. Residential Information Technology Energy Consumption in 2005 and 2010 report is the most thorough information about items that make up LAMELs (Roth et al. 2006), but the use patterns are calculated based on equations and are not specifically monitored. Some studies, such as the Energy Information Agency Residential Energy Consumption Survey (EIA 2005), did homeowner surveys to estimate use patterns, but respondents may believe their uses are different than actual monitored data.

The Consortium for Advanced Residential Buildings (CARB) partnered with WPPI Energy to answer key research questions about in-field performance of GSHPs and LAMELs through extensive field monitoring at two WPPI GreenMax demonstration homes in Wisconsin. CARB installed extensive monitoring equipment in each home to record the energy use of major equipment at 15-min intervals. Monitored loads include space conditioning, water heating, washer/dryer, microwave oven, coffee maker, range/stove, dishwasher, lighting, and plug loads.

CARB developed a monitoring protocol for GSHPs to effectively quantify the whole-system performance of these units, accounting for the ground loop pump, ductwork, and desuperheater. The National Renewable Energy Laboratory is revising this testing protocol into a formal document to be published next year.

These two test home evaluations provided valuable data about the true in-field performance of various building mechanical systems and LAMELs. This information, though a small sample set, validates the Building America House Simulation Protocol's homeowner use patterns. 
The measured steady-state heating coefficient of performance (COP) for low- and high-stage operation of the Black River Falls GSHP system was 3.1, which is 31\% and 23\% less than the rated unit efficiency, respectively. The steady-state cooling energy efficiency ratio for the low stage was 18.1 and for the high stage was 15.9 , which is $23 \%$ and $14 \%$ less than the rated unit efficiency, respectively.

The measured steady state heating COP for low and high stage operation of the Stoughton GSHP system was 2.7 , which is $47 \%$ and $36 \%$ less than the rated unit efficiency, respectively. The steady-state cooling energy efficiency ratio for the low stage was 16.7 , which is $44 \%$ less than the rated unit efficiency. This system rarely operated in high-stage cooling.

The water heating configurations varied significantly between the two homes. The measured COPs for water heating ranged from 1.5 to 3.0; impacts of the different system configurations are discussed more thoroughly in Section 3.2.4. The drain water heat recovery systems at these homes provided a passive $5 \%-10 \%$ contribution to water heating.

Though the 2005 Residential Energy Consumption Survey data suggest that LAMELs are on average $26 \%$ of the overall electricity use in Midwest homes, both of these homes have higher percentages of LAMEL electricity consumption. The Black River Falls home is at 34\% and the Stoughton home is at $41 \%$. As the most efficient lighting and appliances available today have been installed in these homes, much of this electricity consumption falls under miscellaneous electric loads (MELs). For the Black River Falls home, MELs are roughly 17\% (9\% from outlets and $8 \%$ from other sources). For the Stoughton home, MELs are roughly $20 \%$ of the overall electricity use. As technology continues to inundate our lives, the entertainment center is becoming a larger energy hog. The Black River Falls home had roughly $12.4 \%$ of its LAMELs electricity use or $4.2 \%$ of its overall electricity use attributed to the primary entertainment center. 


\section{Introduction}

Through the U.S. Department of Energy's (DOE) Building America (BA) program, the Consortium for Advanced Residential Buildings (CARB), led by Steven Winter Associates Inc., partnered with WPPI Energy to monitor the energy performance of two homes - designed to be net-zero energy - as part of WPPI's GreenMax Homes Program in Wisconsin. These homes included advanced efficiency measures such as improved building envelopes, ground source heat pumps (GSHPs) for space conditioning and domestic hot water (DHW), desuperheaters, drain water heat recovery (DWHR), energy recovery ventilators (ERVs), and two-axis tracking photovoltaic (PV) systems. These demonstration homes have provided a wealth of information for the building community in terms of the science, effort, and cost of increasing the energy efficiency of the U.S. housing stock. Preliminary results for these houses were discussed in two previous reports (CARB 2010, Puttagunta 2010).

BA continues to seek further confirmation of the true performance of homes and advanced mechanical systems through long-term field monitoring. Extensive monitoring of occupied homes provides valuable data that cannot be duplicated through laboratory tests and energy modeling. CARB installed extensive monitoring equipment in each home to record the energy use of major equipment at 15-minute increments. Monitored loads include space conditioning, water heating, washer/dryer, microwave oven, coffee maker, range/stove, dishwasher, lighting, and plug loads.

Energy monitoring enabled tracking of the energy performance of the house, and analysis of the energy consumption data gave an indication of how much energy was saved by the energy efficiency measures included in this project. Extensive monitoring of individual electricity loads allowed for comparisons against energy modeling software and the 2010 BA House Simulation Protocols (HSP). Comparison of these results includes the accuracy of the simulation software for predicting equipment energy use as well as the accuracy of the simulation protocols in modeling the magnitude and use patterns of lighting, appliances, and miscellaneous electric loads (LAMELs). Furthermore, extensive data collection allows for accurate and detailed analysis of the performance and efficiency of individual equipment.

\subsection{Demonstration Homes}

Over the past two years, CARB partnered with WPPI Energy on two of its GreenMax Demonstration Projects in Wisconsin. These two homes were extensively monitored to evaluate the performance of GSHPs, desuperheaters, dual-tracking PV systems, water heating systems, DWHR units, ERVs, and most electric loads (major appliances, lighting, and outlets, where possible) in the homes.

Approximately 150 miles apart, these test homes are located in the International Energy Conservation Code Cold Climate Zone 6A. Stoughton and Black River Falls have similar latitude, cooling degree days (CDDs), heating degree days (HDDs), and average rainfall, as shown in Table 1. 
Table 1. Climate Information

\begin{tabular}{c|c|c|c|c|c}
\hline House & Climate Zone & Latitude & $\begin{array}{c}\text { HDDs } \\
\left(\mathbf{6 5}^{\circ} \mathbf{F} \text { base) }\right.\end{array}$ & $\begin{array}{c}\text { CDDs } \\
\left(\mathbf{6 5}^{\circ} \mathbf{F} \text { base) }\right)\end{array}$ & $\begin{array}{c}\text { Average } \\
\text { Rainfall } \\
\text { (in.) }\end{array}$ \\
\hline Black River Falls & Cold (6A) & $42^{\circ} \mathrm{N}$ & 7,755 & 426 & 34 \\
\hline Stoughton & Cold (6A) & $42^{\circ} \mathrm{N}$ & 7,772 & 305 & 33 \\
\hline
\end{tabular}

The first GreenMax project, a modernist home (Figure 1) located in Black River Falls, Wisconsin, was monitored between June 2009 and June 2011. Key features of this home include $2 \times 8$ wall construction, exterior rigid insulation (R-5 above grade and R-10 below grade), a three-mode GSHP (heating, cooling, hot water), and a 5.76-kW dual-tracking solar PV system. Daily and monthly data from this monitoring are available on WPPI's GreenMax website (WPPI 2011a).

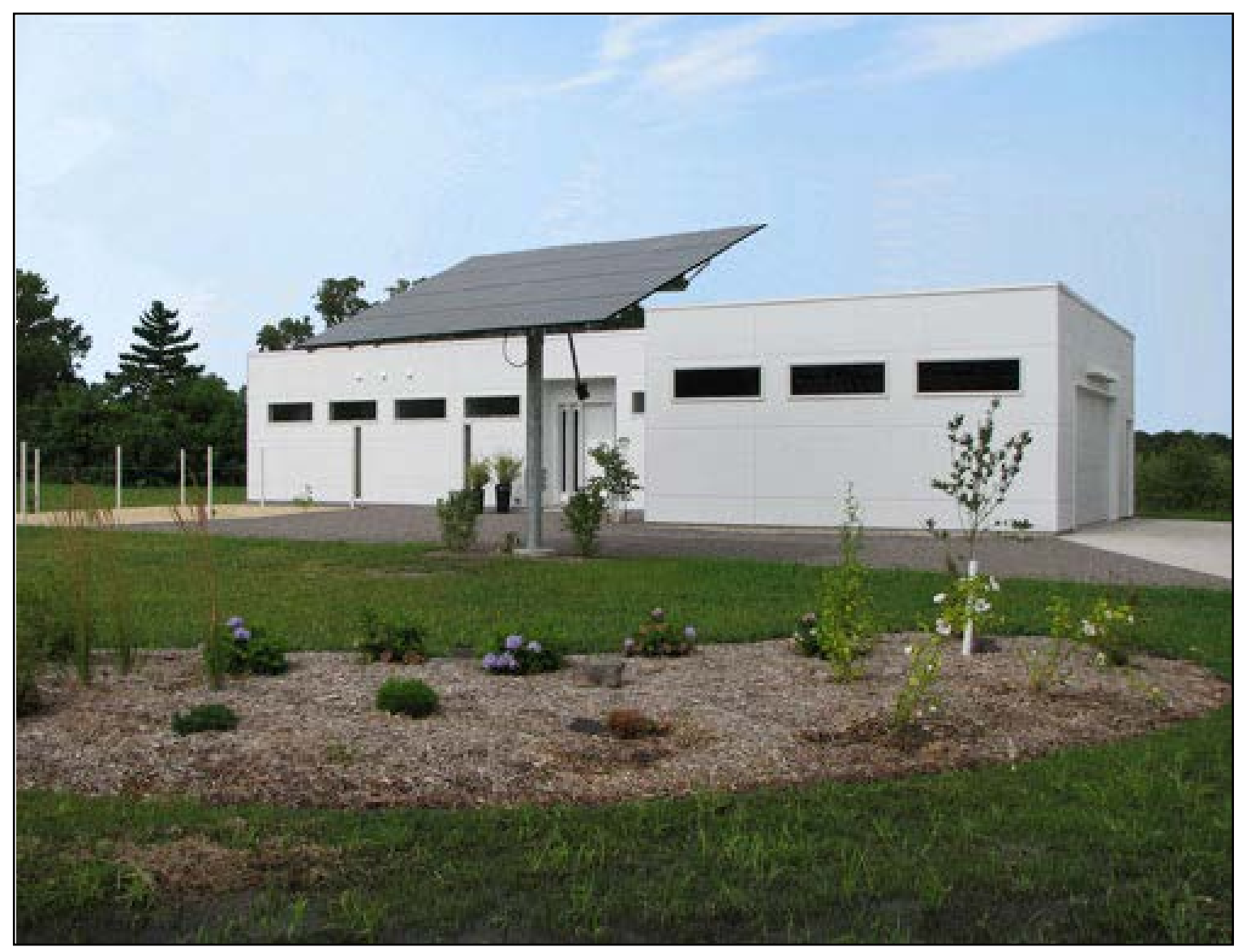

Figure 1. GreenMax home in Black River Falls, Wisconsin

(image courtesy of WPPI Energy)

The second GreenMax project, a more traditional two-story colonial home (Figure 2) located in Stoughton, Wisconsin, was monitored between May 2010 and June 2011. During the design phase, CARB provided recommendations based on hourly energy simulations and a review of the building specifications and drawings. Most BA recommendations were geared toward durability and comfort, including adding a capillary break to the foundation assembly, adding an 
ERV, and designing efficient ductwork. The focus was on developing a cost-effective technology package that would achieve 50+\% source-energy savings over typical mid-1990s construction prior to the use of site generation (PV). Source energy is defined as the sum of the energy consumed at a residence and the energy required to extract, convert, and transmit that energy to the residence. Key features of this home include $2 \times 6$ advanced framed wall construction, two GSHPs (a water-to-air for space conditioning and a water-to-water for domestic water heating), exterior rigid insulation (R-5 above grade and R-10 below grade), and a 5.76-kW dual-tracking solar PV system. Daily and monthly data from this monitoring are available on WPPI's GreenMax website (WPPI 2011b).

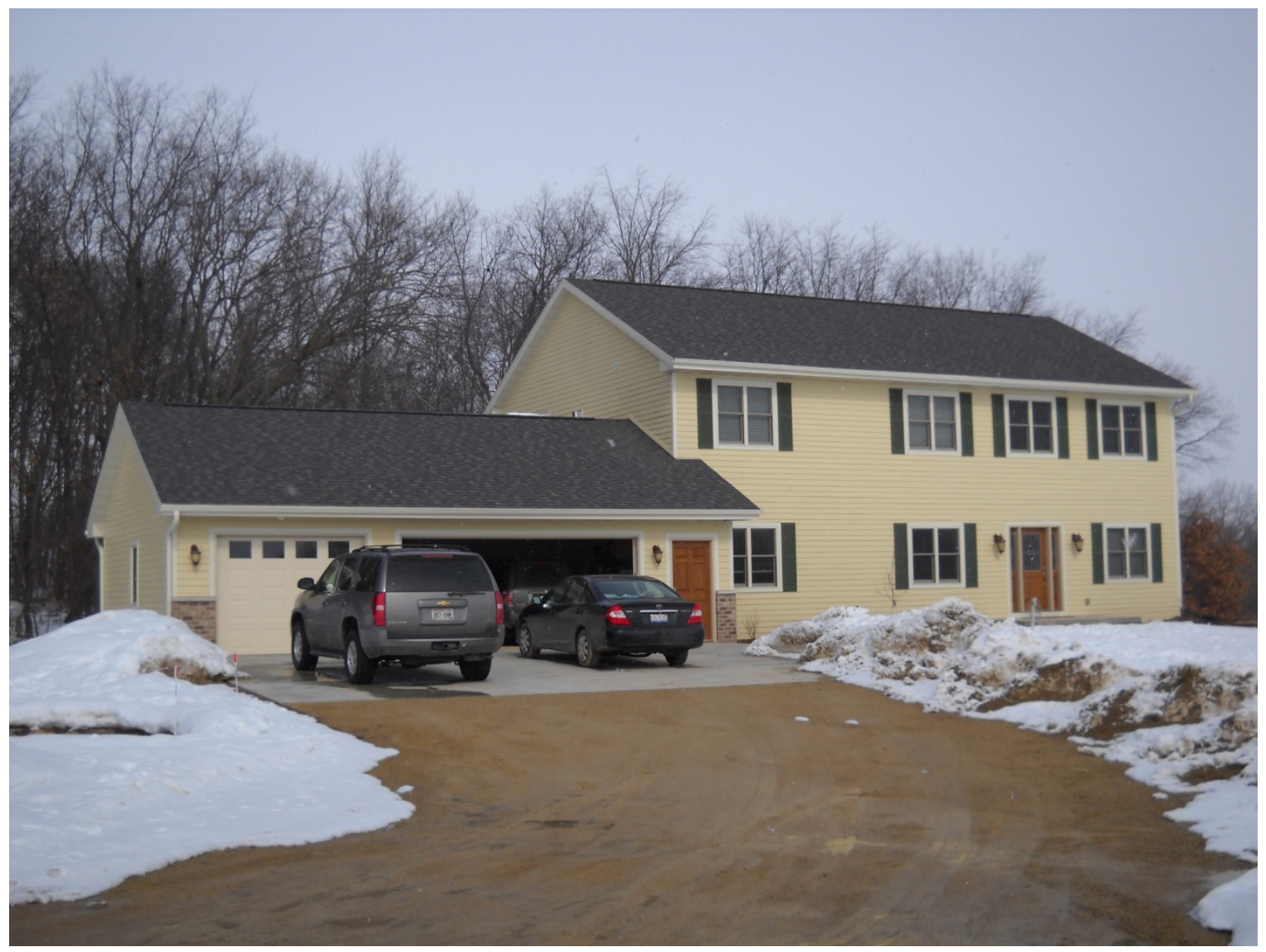

Figure 2. GreenMax home in Stoughton, Wisconsin

The Stoughton home is likely a more applicable case study than the Black River Falls home, because the house and occupants (two adults, one newborn child, and one in-law) are a better reflection of a typical U.S. household. Detailed building specifications for each home in addition to the descriptions above are shown in Table 2. 
Table 2. Building Specifications for Test Homes

\begin{tabular}{|c|c|c|}
\hline Specification & Black River Falls & Stoughton \\
\hline Floor Area & 2,352 & 4,638 \\
\hline Beds & 3 & 5 \\
\hline Bathrooms & 2 & 3.5 \\
\hline Occupants & 2 & 4 \\
\hline $\begin{array}{l}\text { Above-Grade } \\
\text { Wall Assembly }\end{array}$ & $\begin{array}{c}2 \times 8 \text { studwalls@24-in. on center + R-27 } \\
\text { cavity insulation and R-5 rigid insulation on } \\
\text { exterior }\end{array}$ & $\begin{array}{c}2 \times 6 \text { wood framing @ 24-in. on center w/ } \\
\text { hybrid cavity insulation }(\sim 1.1 \text {-in. R-6.5 } \\
\text { closed cell spray foam + R-19 blown } \\
\text { fiberglass) and 1-in. R-5 extruded } \\
\text { polystyrene foam on exterior }\end{array}$ \\
\hline $\begin{array}{l}\text { Foundation } \\
\text { Assembly }\end{array}$ & $\begin{array}{l}\text { R-10 on exterior of foundation walls and under } \\
\text { slab, } 2 \times 4 \text { wood framing w/R-11 unfaced } \\
\text { FGB** }\end{array}$ & $\begin{array}{l}\text { 1-in. R-5 rigid insulation on exterior with } \\
\text { 1-in. R-5 Tuff-n-Dry, } 2 \times 4 \text { wood framing } \\
\text { w/R-13 unfaced FGB, } 2 \text { in. of rigid foam } \\
\text { under slab with 6-mil vapor barrier, } \\
\text { capillary break for footing }\end{array}$ \\
\hline $\begin{array}{l}\text { Ceiling } \\
\text { Assembly }\end{array}$ & R-50 flat ceiling & $\begin{array}{l}\text { R-50 loose fill fiberglass with } 4 \text { mil } \\
\text { ceiling polyethylene, energy heel truss }\end{array}$ \\
\hline Air Sealing & $\begin{array}{l}\text { Air sealing package: spray foam rim/band, caulk } \\
\text { framing, foam penetrations to exterior and } \\
\text { through top/bottom plates }\end{array}$ & $\begin{array}{l}\text { air sealing package: spray foam rim/band, } \\
\text { caulk framing, foam penetrations to } \\
\text { exterior and through top/bottom plates }\end{array}$ \\
\hline Garage Walls & $\begin{array}{c}\text { Interzonal wall (between garage and living } \\
\text { space): R-27 cavity insulation with continuous } \\
\text { air barrier }\end{array}$ & $\begin{array}{l}\text { Interzonal wall (between garage and } \\
\text { living space): R-21 fiberglass BIBS }{ }^{\dagger \dagger \dagger} \\
\text { system with continuous air barrier }\end{array}$ \\
\hline Garage Ceiling & R-50 flat ceiling & R-19 FGB \\
\hline $\begin{array}{l}\text { Building } \\
\text { Infiltration }\end{array}$ & $700 \mathrm{cfm}_{50} / 1.79 \mathrm{ACH}_{50} / 0.09 \mathrm{ACH}_{\text {natural }}$ & $351 \mathrm{cfm}_{50} / 0.52 \mathrm{ACH}_{50} / 0.03 \mathrm{ACH}_{\text {natural }}$ \\
\hline $\begin{array}{l}\text { Window } \\
\text { Glazing }\end{array}$ & $\begin{array}{l}\text { Anderson High Performance Low-E4 double- } \\
\text { glazed windows (U-0.29/SHGC***-21) }\end{array}$ & $\begin{array}{l}\text { Loewen Heat-Smart Plus } 2 \text { triple-glazed, } \\
\text { low-e }^{2} \text {, argon (U-0.19/SHGC-0.21) }\end{array}$ \\
\hline Cooling System & $\begin{array}{l}\text { WaterFurnace Synergy 3-D SDV038 GSHP } \\
\qquad\left(18.5 \mathrm{EER}^{\dagger} / 4.0 \mathrm{COP}\right)\end{array}$ & $\begin{array}{l}\text { WaterFurnace Envision NDV038 GSHP } \\
\text { (20.1 EER/4.2 COP) }\end{array}$ \\
\hline $\begin{array}{l}\text { Heating } \\
\text { System }\end{array}$ & $\begin{array}{l}\text { WaterFurnace Synergy 3-D SDV038 GSHP } \\
\text { (18.5 EER/4.0 COP })\end{array}$ & $\begin{array}{l}\text { WaterFurnace Envision NDV038 GSHP } \\
\text { (20.1 EER/4.2 COP) }\end{array}$ \\
\hline $\begin{array}{l}\text { HVAC* } \\
\text { Controls }\end{array}$ & Programmable thermostat & 3-zone control, programmable thermostat \\
\hline Ductwork & Negligible leakage & Negligible leakage \\
\hline $\begin{array}{l}\text { Whole-House } \\
\text { Ventilation }\end{array}$ & $\begin{array}{l}\text { Enerflow NRFLOE ERV (passive, no internal } \\
\text { fans) }\end{array}$ & RenewAire $90 \mathrm{cfm}$ ERV \\
\hline $\begin{array}{l}\text { Point-Source } \\
\text { Ventilation }\end{array}$ & $\begin{array}{c}50-80 \mathrm{cfm} \text { fans for all bathrooms, kitchen } \\
\text { exhaust hood ducted to outside }\end{array}$ & $\begin{array}{c}\text { Panasonic WhisperGreen FV-05(08)VK1 } \\
\text { for all bathrooms, kitchen exhaust hood } \\
\text { ducted to outside }\end{array}$ \\
\hline $\begin{array}{c}\text { Domestic } \\
\text { Water Heating }\end{array}$ & $\begin{array}{c}\text { WaterFurnace Synergy 3-D SDV038 GSHP ( } 2.6 \\
\text { COP) and a Marathon MR105 electric resistance } \\
\text { tank water heater }\end{array}$ & $\begin{array}{l}\text { WaterFurnace Envision EW020 water-to- } \\
\text { water GSHP ( } 2.8 \mathrm{COP})\end{array}$ \\
\hline PV & $5.76 \mathrm{~kW}$ with dual axis tracking & $5.76 \mathrm{~kW}$ with dual-axis tracking \\
\hline Lighting & $100 \%$ fluorescent or LED ${ }^{\dagger \dagger}$ lighting & $100 \%$ fluorescent or LED lighting \\
\hline Appliances & $\begin{array}{l}\text { ENERGY STAR refrigerator, dishwasher, } \\
\text { clothes washer }\end{array}$ & $\begin{array}{l}\text { ENERGY STAR refrigerator, dishwasher, } \\
\text { clothes washer }\end{array}$ \\
\hline $\begin{array}{ll}* \mathrm{H} \\
{ }^{\dagger} \mathrm{E}\end{array}$ & $\begin{array}{ll}\text {, and air conditioning } & * * \text { Fiberglass ba } \\
\text { tio } & { }^{\dagger} \text { Light-emitting }\end{array}$ & $\begin{array}{ll} & * * * \text { Solar heat gain coefficient } \\
\text { iode } \quad{ }^{\dagger \dagger} \text { Blow-in-basket system }\end{array}$ \\
\hline
\end{tabular}




\subsection{Research Questions}

The intent of evaluating various building mechanical systems and LAMELs in these two test homes was to obtain valuable information for consumers and builders about strategies to provide effective near-zero electrical homes. This information also was used to validate the BA HSP homeowner use patterns. This research effort focused on answering the following research questions:

- What is the installed system efficiency of these GSHPs? How do these differ from the units' rated efficiencies?

- How effective are GSHPs in providing domestic water heating?

- Is DWHR effective in single-family homes and what are the major drivers in its performance?

- What are the major contributors to LAMELs in these homes?

\subsection{Expected Energy Savings Over Building America Benchmark}

With highly efficient equipment and advanced building specifications, the GreenMax demonstration homes will show significant energy savings over a new home built to typical construction specifications. EnergyGauge USA v2.8.03 (EGUSA), an hourly energy simulation tool, was used to analyze the predicted cost savings over the BA Benchmark home. EGUSA was chosen over BEopt, the National Renewable Energy Laboratory's (NREL) hourly simulation tool, because BEopt cannot yet model GSHPs. The 2008 BA Benchmark (Hendron 2008) was used because these homes were constructed before the most recent update to the benchmark. The B08 Benchmark is consistent with mid-1990s standard building practice for a particular climate zone. These homes meet the BA goal of $50+\%$ whole-house source energy savings, as shown in Table 3 .

Table 3. Source Energy Savings over BA B08 Benchmark

\begin{tabular}{c|c|c|c}
\hline House & $\begin{array}{c}\text { Annual Source Energy } \\
\text { of B08 Benchmark } \\
\text { (MMBtu/year) }\end{array}$ & $\begin{array}{c}\text { Annual Source Energy } \\
\text { of Demonstration Home } \\
\text { (MMBtu/year) }\end{array}$ & $\begin{array}{c}\text { \% Savings } \\
\text { Over B08 } \\
\text { Benchmark }\end{array}$ \\
\hline Black River Falls & 400 & 151 & $62.3 \%$ \\
Stoughton & 522 & 197 & $60.5 \%$ \\
\hline
\end{tabular}

\subsection{Partners}

WPPI Energy is a regional power company serving 51 customer-owned electric utilities that share resources and own generation facilities to provide electricity to more than 192,000 homes and businesses in Wisconsin, Upper Michigan, and Iowa.

WPPI Energy's GreenMax Home initiative is designed to encourage the building or remodeling of homes that use reliable, sustainable energy systems. Program funding shares the incremental cost of building or remodeling a net zero energy home. The home designs and occupant lifestyles required to achieve net zero energy use must be replicable and appropriate for a mass market, community-based setting. 


\section{Energy Consumption Overview}

According to the 2000 Energy Center of Wisconsin's "Energy and Housing in Wisconsin" study, Wisconsin homes using natural gas for heating, which represent approximately $70 \%$ of the state's housing stock, use an average of 9,960 kWh of electricity and 1,026 therms of natural gas annually (Pigg and Nevius 2000). The average electricity use of all-electric homes, which represent less than $5 \%$ of the state's housing stock, is $24,000 \mathrm{kWh}$ annually.

The annualized energy usage of the two GreenMax demonstration homes, which are both allelectric (except for propane fireplaces in the Stoughton residence that are rarely used), was considerably less than the average Wisconsin energy use. The average annual electricity consumption and generation for both houses are shown in Table 4. Both houses consumed slightly more electricity than produced by the PV system; the homes were close to the net-zero energy goal. The total net electricity use for the Black River Falls and Stoughton homes were 127 and 3,312 kWh, respectively. The Black River Falls and Stoughton houses consumed 62\% and $41 \%$ less energy than the average all-electric Wisconsin house, respectively, when PV generation was ignored.

Table 4. Average Annual Energy Consumption and Generation by House

\begin{tabular}{c|c|c|c}
\hline House & $\begin{array}{c}\text { Average Annual } \\
\text { Electricity Consumption } \\
(\mathbf{k W h})\end{array}$ & $\begin{array}{c}\text { Average Annual } \\
\text { Electricity Generation } \\
\mathbf{( k W h )}\end{array}$ & $\begin{array}{c}\text { Net Electricity } \\
\text { Use } \\
(\mathbf{k W h})\end{array}$ \\
\hline Black River Falls & 9,280 & 9,143 & 127 \\
Stoughton & 14,204 & 10,892 & 3,312 \\
\hline
\end{tabular}

The average annual electricity generation of the Black River Falls home was lower than anticipated because a malfunctioning inverter resulted in minimal PV generation in January and February 2011. The inverter was replaced in late February 2011, and generation totals have been comparable between the two sites since. If the inverter had not malfunctioned, annual generation is estimated at 9,973 kWh. In this scenario, the Black River Falls home would have been a net producer of electricity with a net generation of $693 \mathrm{kWh} / \mathrm{yr}$.

\subsection{Energy Consumption Breakdown}

The energy consumption of each home by end use is shown in Figure 3 and Figure 4 . The largest energy consumers are the space conditioning and water heating GSHP systems. Appliances are the third-largest energy consumer followed by other electricity uses (such as lights, outlets, and other miscellaneous electric loads [MELs]). Energy consumption and generation for each home by month for the enitre monitoring peroid are shown in Figure 6 and Figure 7.

During the summer months electricity generation was greater than electricity consumption because of smaller space conditioning loads and more solar radiation. During the winter months, on the other hand, electricity consumption was greater than generation because of larger space heating loads and less solar radiation. 


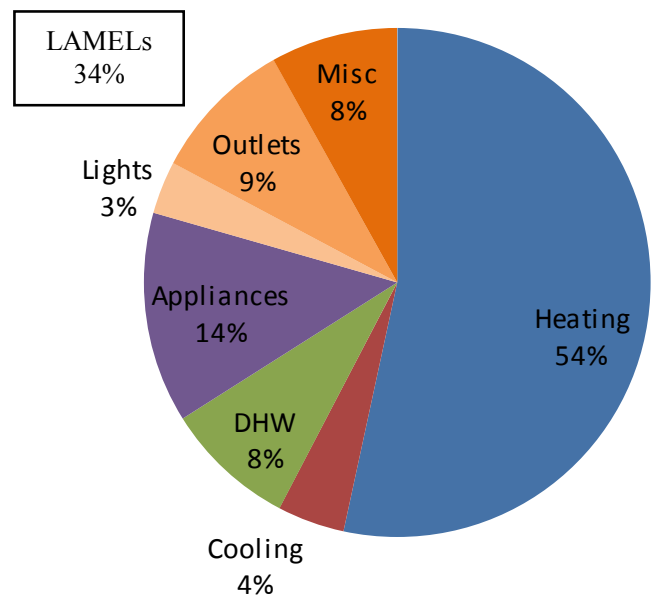

Figure 3. Site energy consumption by end use for Black River Falls home

The average site energy consumption by end use for an average home in the East North Central states (Wisconsin, Michigan, Ohio, Indiana, and Illinois) is shown in Figure 5 (EIA 2005). The results from the Stoughton home match end-use energy predictions: the highly efficient building shell and mechanical equipment minimize heating, cooling, and DHW; this causes the LAMELs to consume a larger proportion of the total electric load. The Black River Falls home, however, does not show this trend, most likely because this home has only two occupants.

Figure 6 and Figure 7 show the data provided in Figure 3 and Figure 4, respectively, in an average monthly bar chart format. The solar PV generation is also provided for each month.

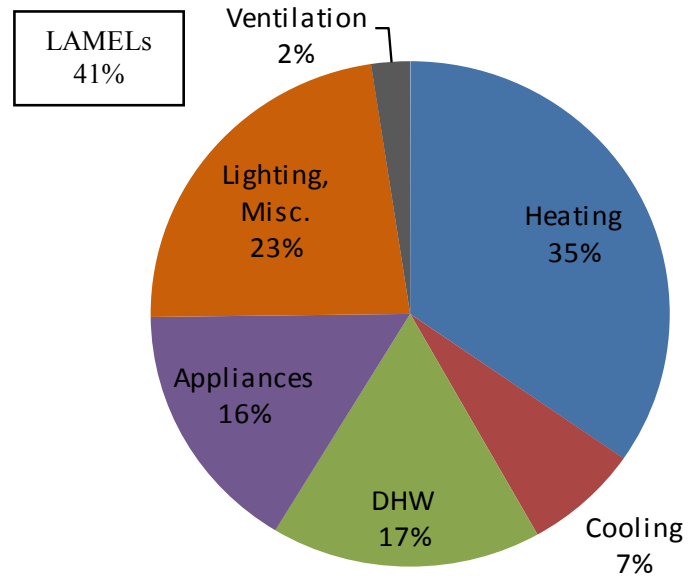

Figure 4. Site energy consumption by end use for Stoughton home

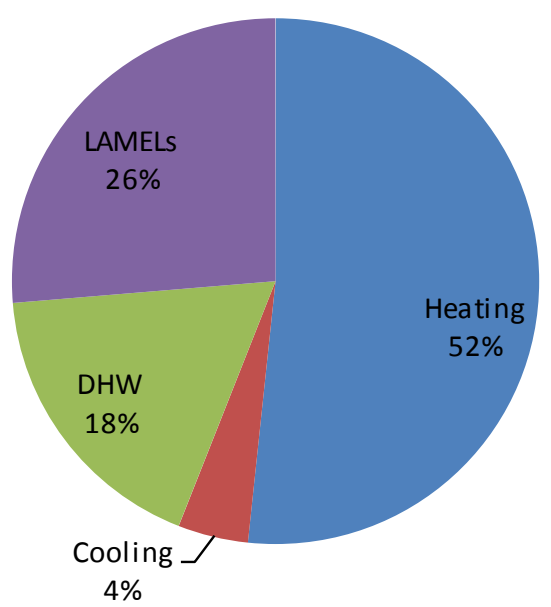

Figure 5. Site energy consumption by end use for average home in Midwest - East North Central

(EIA 2005)

It is clear from these figures that space heating is the dominant source of energy consumption. Unfortunately, the peak for the space conditioning (winter dominant) is the exact opposite of the solar PV generation (summer dominant), so net metering is critical to achieving energy neutrality over the course of the year. It is also evident that besides the space conditioning energy consumption, the energy consumption of the other components is fairly varied for the Black River Falls home versus the more uniform monthly consumption pattern of the Stoughton home. 


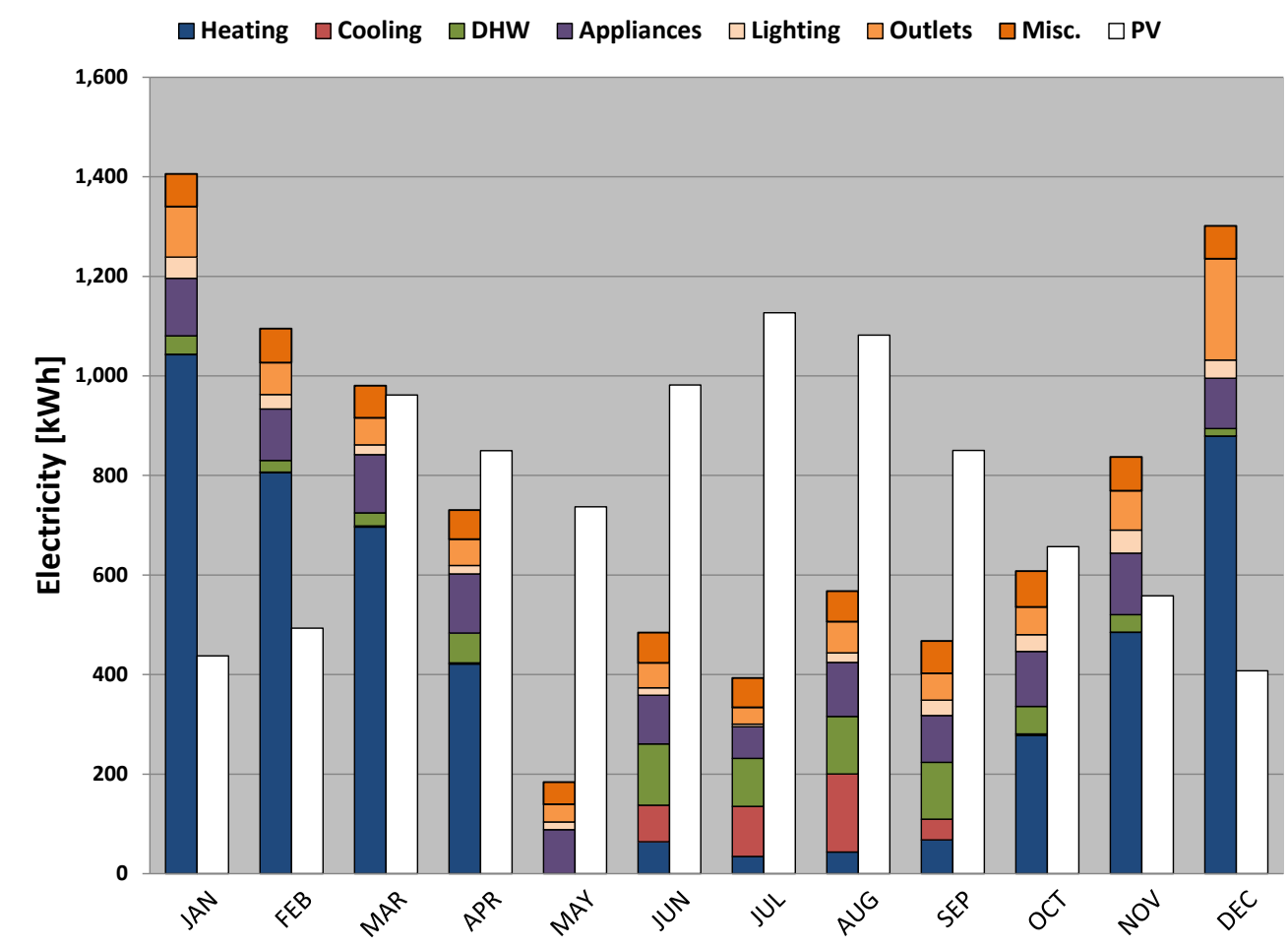

Figure 6. Mean monthly site energy component breakdown and generation of Black River Falls home

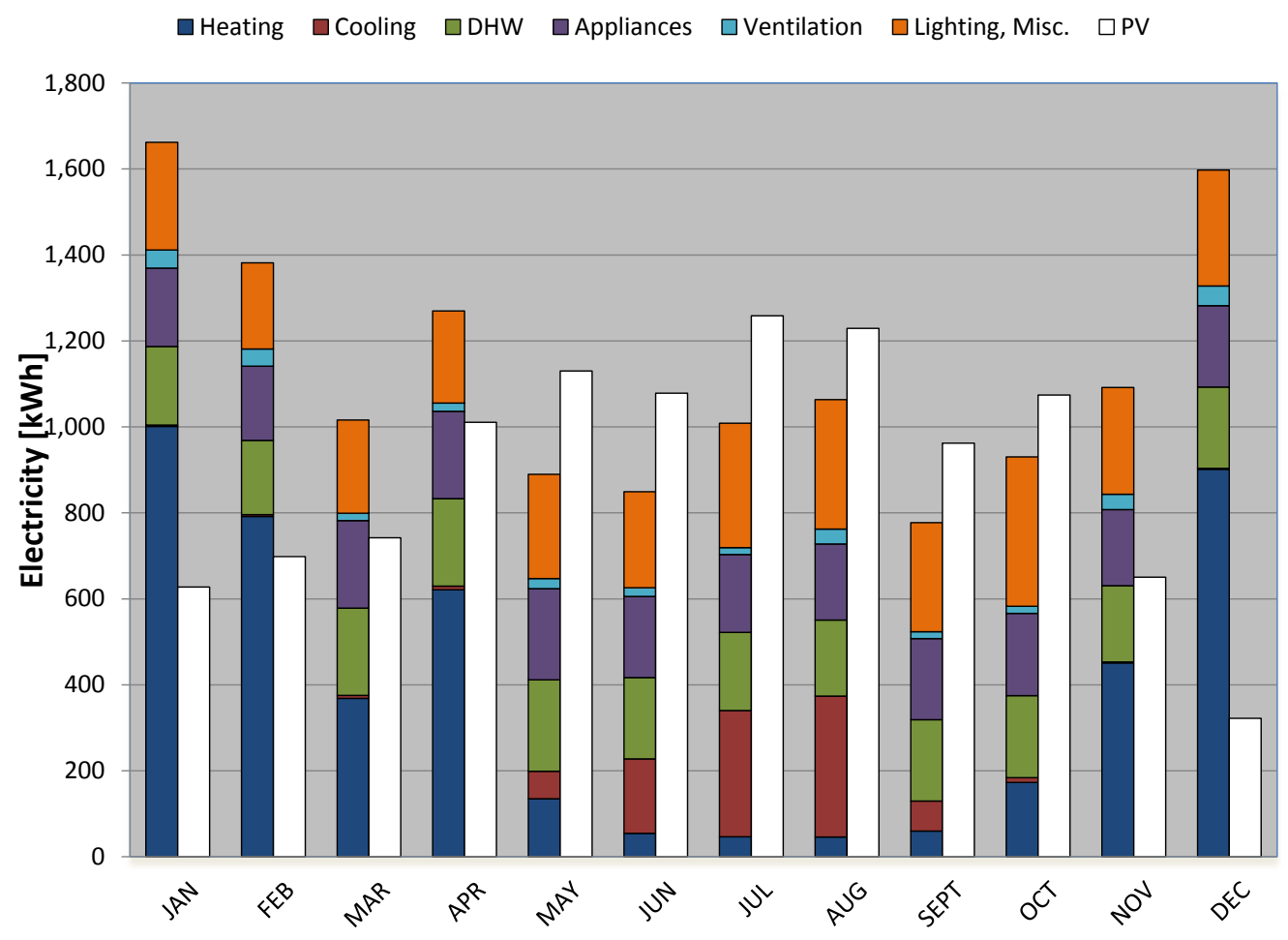

Figure 7. Mean monthly site energy component breakdown and generation of Stoughton home 


\section{Ground Source Heat Pump}

A GSHP system was installed in both houses to supply space heating, space cooling, and DHW. Each system uses a horizontal closed, pressurized, slinky ground loop consisting of two trenches at a depth of $8 \mathrm{ft}$. Environol 1000 solution (21.4\% ethanol) is circulated between the ground coils and the GSHPs, which are located in the unfinished portions of the basements. Although these systems are very similar, there are some differences.

The Black River Falls home has two 300- $\mathrm{ft}$ trenches at a depth of $8 \mathrm{ft}$ and separated by $8 \mathrm{ft}$. A triple-mode GSHP (WaterFurnace Synergy 3-D 3-ton dual speed heat pump) provides space heating, space cooling, and DHW from the same unit. A desuperheater runs directly to the electric water heater. A passive ERV, which has no internal fans and uses the air handler to move air through it, was connected to the central duct system, but this has been replaced with a typical heat recovery ventilator with internal fans (currently not interlocked with the GSHP air handler fan).

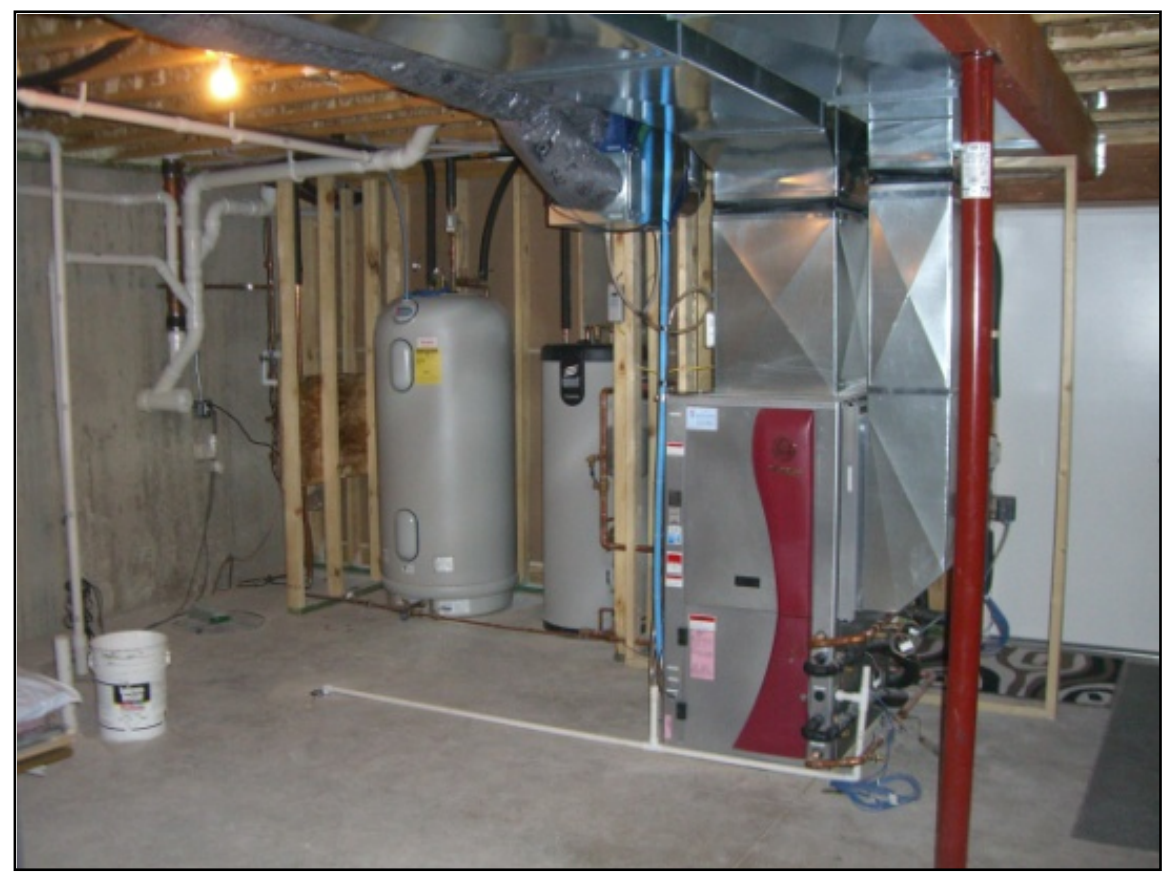

Figure 8. Black River Falls GSHP system

The Stoughton system has two 110 - $\mathrm{ft}$ trenches at a depth of $8 \mathrm{ft}$ and separated by $15 \mathrm{ft}$. Two separate GSHPs provide space conditioning (WaterFurnace Envision 3-ton dual-speed heat pump) and DHW (WaterFurnace ESeries 2-ton). A desuperheater runs from the Envision to a 50gal preheat storage tank. The ESeries runs to an 80 -gal primary tank. There is no auxiliary water heating source.

CARB contacted both HVAC contractors that installed these two systems, but they did not have a clear explanation about why the Black River Falls ground loop field is larger than the Stoughton installation. The Stoughton home has a larger building load and an additional GSHP for water heating, so we would anticipate a larger ground loop field for this site. 


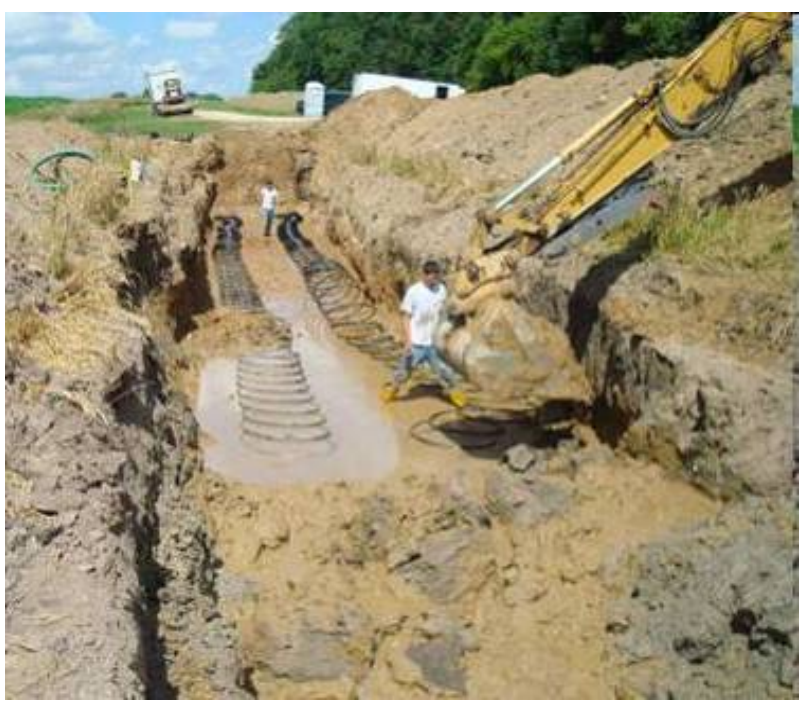

Figure 9 Installation of ground loop at Stoughton residence

(image courtesy of WPPI Energy)

These GSHP systems have EER ratings greater than 18 and COPs greater than 4.0. The International Standards Organization (ISO)/Air-Conditioning and Refrigeration Institute-rated efficiencies of the GHSP models installed in these homes are shown in Table 5.

Table 5. Rated Efficiencies of GSHP Models

\begin{tabular}{c|c|c|c|c|c|c}
\hline \multirow{2}{*}{ GSHP } & $\begin{array}{c}\text { Model } \\
\text { Number }\end{array}$ & House & \multicolumn{2}{c|}{ Low Stage } & \multicolumn{2}{c}{ High Stage } \\
\cline { 4 - 7 } & EER & COP & EER & COP \\
\hline $\begin{array}{c}\text { WaterFurnace Synergy } \\
\text { 3-D heat pump }\end{array}$ & SDV038 & Black River Falls & 23.7 & 4.5 & 18.5 & 4.0 \\
$\begin{array}{c}\text { WaterFurnace Envision } \\
\text { 3-ton dual speed }\end{array}$ & NDV038 & Stoughton & 30.0 & 5.1 & 20.1 & 4.2 \\
$\begin{array}{c}\text { WaterFurnace ESeries } \\
\text { 2-ton }\end{array}$ & EW020H & Stoughton & N/A & N/A & N/A & 2.8 \\
\hline
\end{tabular}

\subsection{Ground Source Heat Pump Efficiency Metrics}

GSHPs are rated in accordance with American Society of Heating, Refrigerating and AirConditioning Engineers (ASHRAE)/ISO 13256-1. Ratings are performed at an entering water temperature of $77^{\circ} \mathrm{F}$ in cooling mode and $32^{\circ} \mathrm{F}$ in heating mode. In terms of the indoor rating conditions, units are tested at an indoor air temperature of $80.6^{\circ} \mathrm{F}$ dry bulb and $66.2^{\circ} \mathrm{F}$ wet bulb (46\% relative humidity) in cooling mode and $68^{\circ} \mathrm{F}$ dry bulb and $59^{\circ} \mathrm{F}$ wet bulb $(58 \%$ relative humidity) in heating mode.

As with other equipment ratings, GSHP ratings apply only to the manufacturer's unit and not to the entire space conditioning system. Installed efficiencies are always below the rated efficiencies. According to ASHRAE/ISO 13256-1, the "effective power input" used in the calculation of COP/EER should include the compressor, the water pump, the air handler fan, and all associated controls. However, fan power used in the calculation of a unit's COP/EER does 
not include flow resistance from ducts, nor does pump power include the resistance of the ground loop. The rationale for this is that the design of the duct system and ground loop is unknown to the manufacturer and this rating method allows for apples-to-apples equipment comparisons. One additional result, however, is that literature COP and EER values are substantially higher than the efficiencies of installed systems.

CARB developed a monitoring protocol for GSHPs to effectively quantify the whole-system performance of these units, accounting for the ground loop pump, ductwork, and desuperheater. NREL is revising our testing protocol into a formal document to be published next year. System efficiency has been defined for this project using Equations (1) and (2). The efficiency of the heating and DHW systems are defined by the COP, which is the dimensionless ratio of useful heating energy output by the system to the net energy input to the system.

$$
C O P=\frac{\text { useful heating energy }}{\text { net energy input }} \quad \text { [dimensionless] }
$$

The efficiency of the cooling system is defined by the EER, which is also the ratio of the useful cooling energy output by the system to the net energy input to the system, but is defined by the units Btu/Wh.

$$
E E R=\frac{\text { useful cooling energy }}{\text { net energy input }} \quad[\mathrm{Btu} / \mathrm{Wh}]
$$

\subsubsection{Heating Coefficient of Performance}

The COP of the entire heating system (not just the heat pump unit) is

$$
C O P_{h}=\frac{Q_{h}+\left(W_{\text {fan }}+W_{\text {comp }}+W_{D S H, p u m p}\right) \times 3.413 \mathrm{Btu} / \mathrm{Wh}}{\left(W_{\text {comp }}+W_{\text {fan }}+W_{\text {pump }}+W_{D S H, \text { pump }}\right) \times 3.413 \mathrm{Btu} / \mathrm{Wh}},
$$

where

$$
\begin{array}{ll}
\mathrm{COP}_{\mathrm{h}} & =\text { coefficient of performance of the complete heating system } \\
& \text { [dimensionless], } \\
\mathrm{Q}_{\mathrm{h}} & =\text { useful heat extracted from ground loop [Btu], } \\
\mathrm{W}_{\text {comp }} & =\text { energy consumed by the compressor [Wh], } \\
\mathrm{W}_{\text {fan }} & =\text { energy consumed by the fan [Wh], } \\
\mathrm{W}_{\text {pump }} & =\text { energy consumed by the ground-loop pump [Wh], and } \\
\mathrm{W}_{\mathrm{DSH}, \mathrm{pump}} & =\text { energy consumed by desuperheater pump [Wh]. }
\end{array}
$$

\subsubsection{Domestic Hot Water Coefficient of Performance}

The COP of the DHW is

$$
C O P_{D H W}=\frac{Q_{h}}{\left(W_{\text {comp }}+W_{\text {pump }}+W_{\text {pump }-2}\right) \times 3.413 \mathrm{Btu} / \mathrm{Wh}},
$$


where

$$
\mathrm{W}_{\text {pump-2 }}=\text { energy consumed by the DHW pump [Wh]. }
$$

\subsubsection{Cooling Energy Efficiency Ratio}

The EER of the cooling system is

$$
E E R=\frac{Q_{c}+Q_{D S H}-\left(W_{f a n}+W_{\text {comp }}\right) \times 3.413 \text { Btu } / W h}{W_{\text {comp }}+W_{\text {fan }}+W_{\text {pump }}+W_{D S H, \text { pump }}},
$$

where

$$
\begin{array}{ll}
\mathrm{EER} & =\text { energy efficiency ratio [Btu/Wh], } \\
\mathrm{Q}_{\mathrm{c}} & =\text { heat dumped to ground loop [Btu], } \\
\mathrm{W}_{\text {comp }} & \text { = energy consumed by the compressor [Wh], } \\
\mathrm{W}_{\text {fan }} & \text { = energy consumed by the fan [Wh], } \\
\mathrm{W}_{\text {pump }} & =\text { energy consumed by the ground-loop pump [Wh], } \\
\mathrm{Q}_{\mathrm{DSH}} & =\text { heat transferred to DWH by desuperheater [Btu], and } \\
\mathrm{W}_{\text {DSH,pump }} & =\text { energy consumed by the desuperheater circulator [Wh]. }
\end{array}
$$

\subsection{Ground Source Heat Pump Monitoring Results}

The overall heating COP and cooling EER were measured at both houses over the entire monitoring period. This accounts for all energy use of the GSHP regardless of whether the system was supplying conditioned air. The efficiency values also included all standby electricity use. In addition, the steady-state efficiencies were calculated for each house and system, where steady-state is defined as the system being in operation for a full 15-min logging interval. The overall and steady-state efficiencies are shown in Table 6.

Table 6. Measured Efficiency of GSHPs

\begin{tabular}{c|c|c|c|c}
\hline \multirow{2}{*}{} & \multicolumn{2}{|c|}{ Black River Falls } & \multicolumn{2}{c}{ Stoughton } \\
\cline { 2 - 5 } & Overall & Steady-State & Overall & Steady-State \\
\hline Heating COP & 2.7 & 3.1 & 2.6 & 2.7 \\
DHW COP & - & 1.9 & 1.4 & 2.0 \\
Cooling EER & 17.5 & 17.0 & 15.0 & 16.7 \\
\hline
\end{tabular}

As shown in Table 6, when the system was running at steady-state, it has a better heating COP performance. These systems are sized for the dominant heating load, and therefore oversized in terms of cooling capacity (even at part-load capacity), resulting in system short-cycling during the cooling season. Short-cycling refers to short run times of the HVAC unit. Starting and stopping equipment at short periods can be detrimental to machine life and drastically minimize the latent capacity of the unit. As there were fewer steady-state operations (as defined for this evaluation) during the cooling cycle and those were primarily at peak conditions (full-stage operation and highest ground loop entering temperatures), the steady-state cooling EER ended up slightly lower than the overall EER. 


\subsubsection{Space Conditioning}

The measured monthly system COP is lower than the rated COP from the engineering data (see Table 7), because the rated COP does not account for the external piping resistance (the ground loop pump energy), fan energy is measured with no blower external static pressure (or no ductwork), and the desuperheater pump energy is not included. Table 7 shows the performance difference between the rated efficiencies and the efficiency of the system as installed. The values below show the steady-state efficiency. Based on the discrepancy between the rated and measured efficiencies, the overall efficiencies of these GSHP systems are not significantly higher than alternative space conditioning methods, especially compared to the new inverter driven compressor air-source heat pumps available in the market.

Table 7. Rated Versus Measured System Efficiencies

\begin{tabular}{c|c|c|c|c|c|c}
\hline & \multicolumn{2}{|c|}{$\begin{array}{c}\text { ISO/ARI Rated Heat } \\
\text { Pump Efficiency } \\
\text { (COP/EER) }\end{array}$} & $\begin{array}{c}\text { Measured Steady State } \\
\text { Efficiency } \\
\text { (COP/EER) }\end{array}$ & \multicolumn{2}{c}{$\begin{array}{c}\text { Performance } \\
\text { Difference } \\
\text { (COP\%/EER\%) }\end{array}$} \\
\cline { 2 - 7 } & Low Stage & High Stage & Low Stage & High Stage & Low Stage & High Stage \\
\hline Black River Falls & $4.5 / 23.7$ & $4.0 / 18.5$ & $3.1 / 18.1$ & $3.1 / 15.9$ & $31 \% / 23 \%$ & $23 \% / 14 \%$ \\
Stoughton & $5.1 / 30.0$ & $4.2 / 20.1$ & $2.7 / 16.7$ & $2.7 /-$ & $47 \% / 44 \%$ & $36 \% / \mathrm{na}$ \\
\hline
\end{tabular}

This difference between the rated efficiency of a heat pump unit and the in-field system efficiency is important when performing energy modeling to estimate home performance. The rated equipment COP entered into common modeling tools is often taken as the effective COP of the modeled system. Some software programs have been corrected to include ground loop pump power. The manufacturers are not to blame, because they can rate only the portion of the product that they manufacture; therefore, designers and contractors need to acknowledge the difference between rated efficiency and system efficiency.

The average monthly measured COP/EER of the Black River Falls system and the manufacturerlisted COP/EER for the heat pump only are shown in Figure 10 and Figure 11, respectively. The Black River Falls system uses a single-speed ground loop pump that is operating at roughly 7.4 gpm. The manufacturer's ratings in the figures are based on ground loop flow rates of 7 gpm for high stage and an interpolated $7 \mathrm{gpm}$ for low stage (manufacturer data provided performance ratings at $6 \mathrm{gpm}$ and $8 \mathrm{gpm}$ ). 


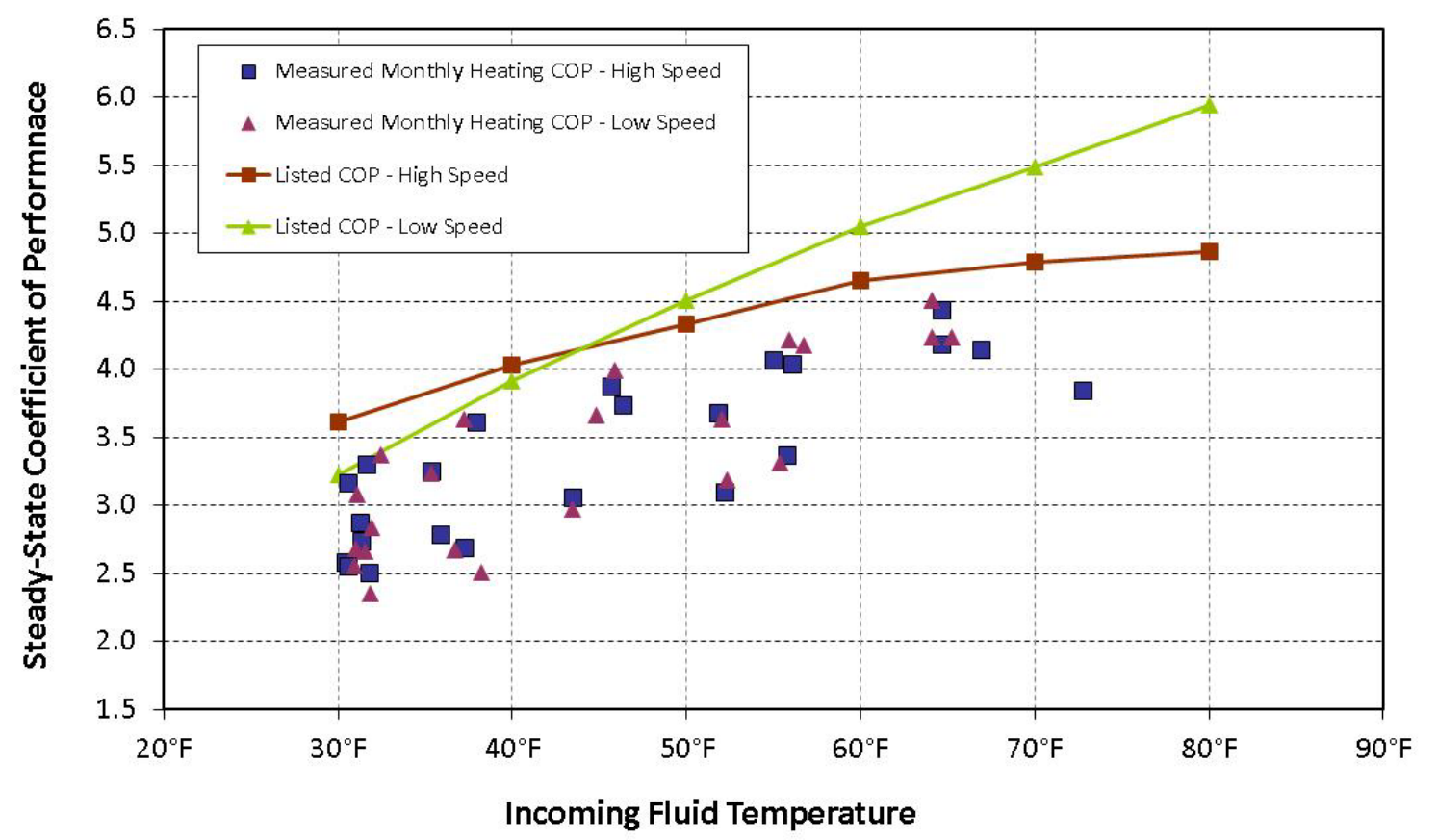

Figure 10. Measured versus literature COP of Black River Falls GSHP for space heating

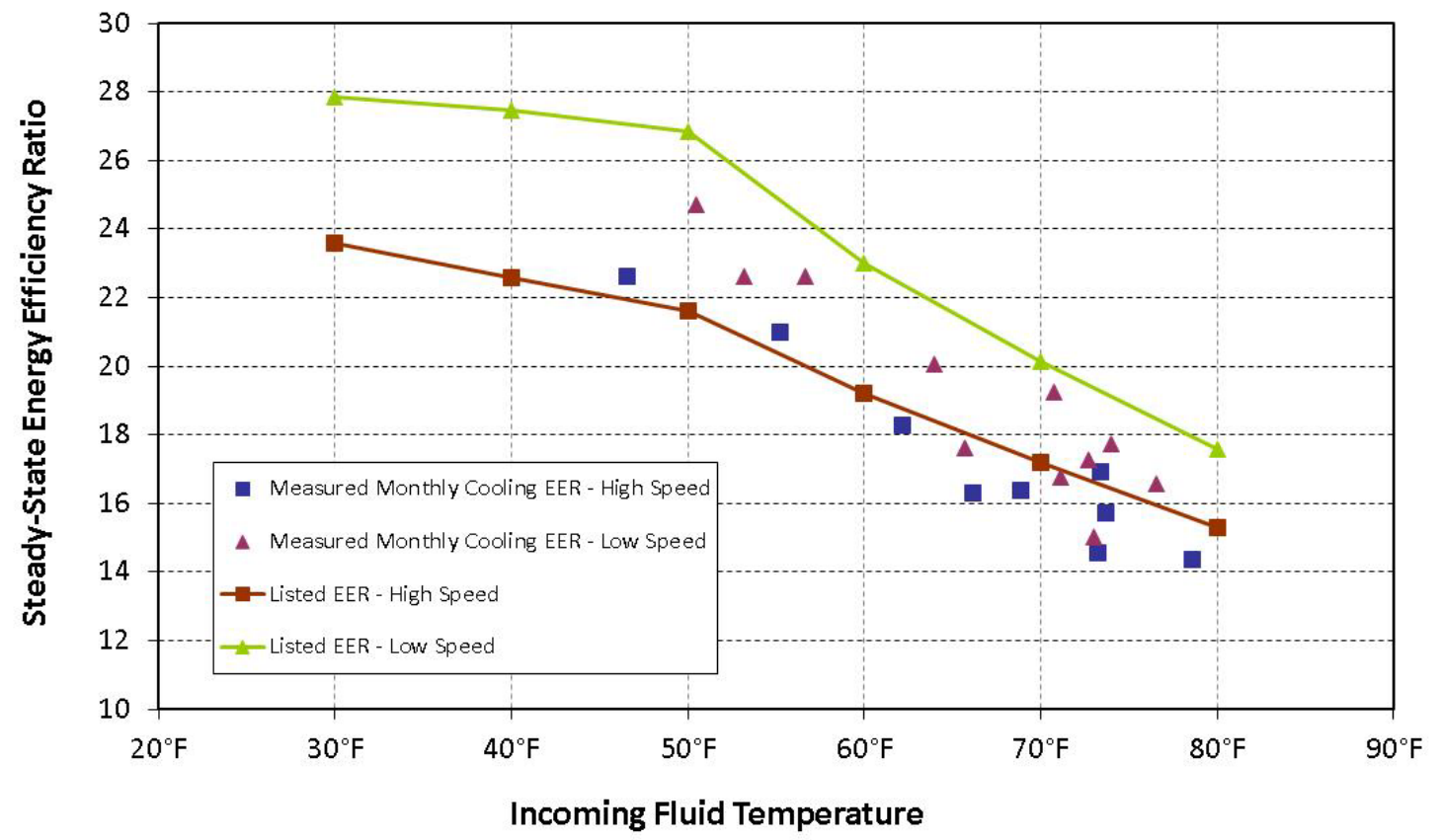

Figure 11. Measured versus literature EER of Black River Falls GSHP for space cooling

The average monthly measured COP/EER of the Stoughton system and the manufacturer-listed COP/EER for the heat pump only are shown in Figure 12 and Figure 13, respectively. The Stoughton system uses a single-speed ground loop pump that is operating at roughly $9.1 \mathrm{gpm}$. The manufacturer's curves displayed are based on ground loop flow rates of $9 \mathrm{gpm}$ for high stage and $8 \mathrm{gpm}$ for low stage, which is the highest flow rate the manufacturer lists for low-stage operation. 


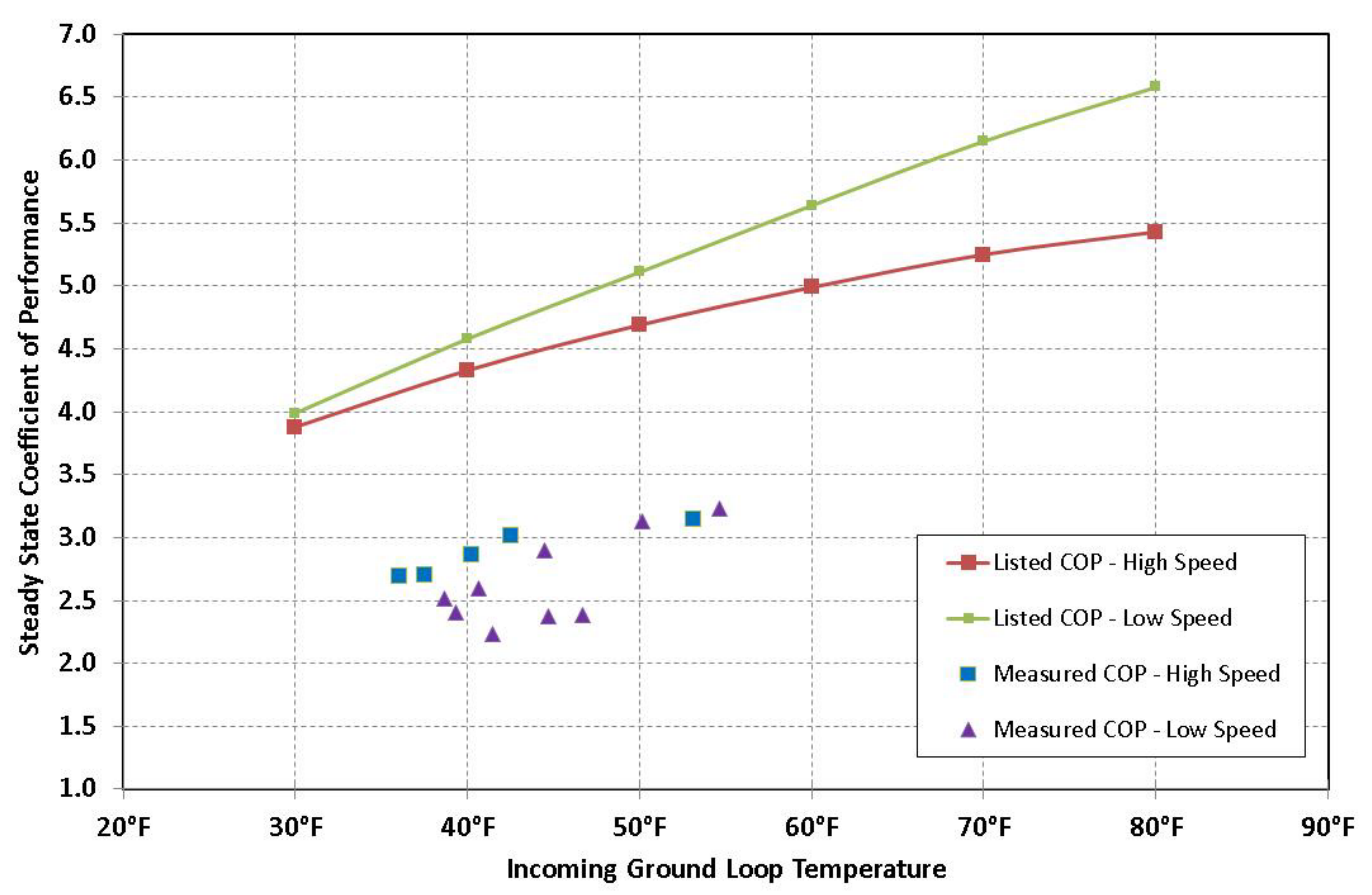

Figure 12. Measured versus literature COP of Stoughton GSHP for space heating

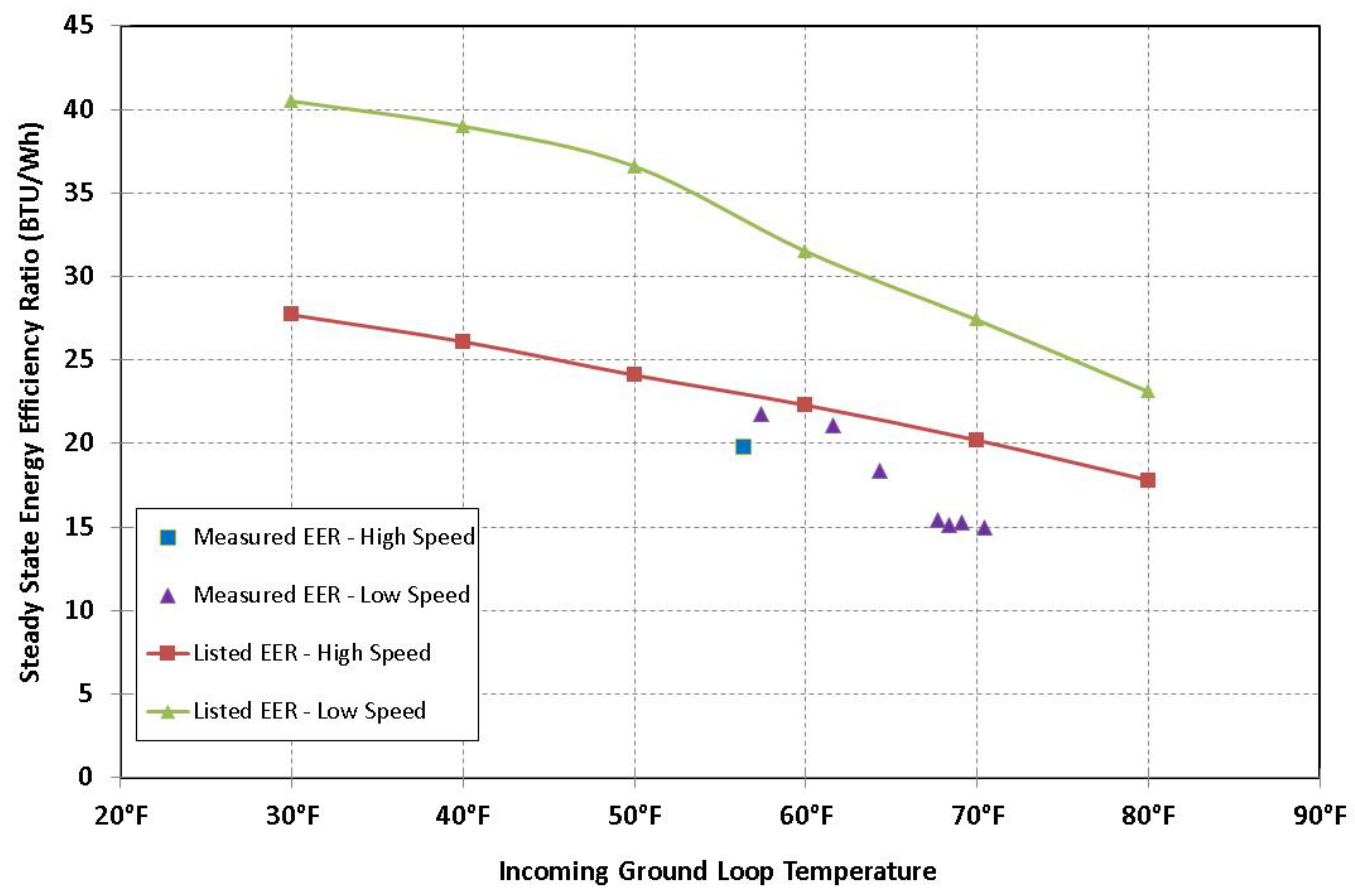

Figure 13. Measured versus literature EER of Stoughton GSHP for space cooling

For both systems, the average COP on high speed (or full-load capacity) is similar to when on low speed, despite the efficiencies indicated on the manufacturers' specification sheets. Depending on the incoming fluid temperature, there may be a benefit from low-stage operation, but nothing comparable to the advertised benefit from the manufacturers' data. This is likely due 
partially to the use of single-speed ground loop pumps for dual-stage compressors and partly due to the rating test procedure.

Interestingly, because of how these systems have been installed and configured, the Synergy 3D GSHP is actually performing better in heating mode (higher COP) than the Envision GSHP, which has a higher rated COP. The Envision GSHP installed at the Stoughton House is being penalized by higher pump energy needed for that design. This system has two GSHPs connected to a single ground loop, and both ground loop pumps run regardless of operation mode.

Even though these two systems are horizontal slinky at a depth of $8 \mathrm{ft}$, the incoming ground loop temperature for the Black River Falls shows a large temperature range over the course of the year $\left(30^{\circ}-80^{\circ} \mathrm{F}\right.$ for the Black River Falls system versus $35^{\circ}-70^{\circ} \mathrm{F}$ for the Stoughton system $)$. Though not verified (as we were unable to install loop field temperature sensors at the Black River Falls installation), it is our theory that this is due to the Black Rive Falls home being located at the top of a slope, about $45 \mathrm{ft}$ above the water, so one side of the ground loop field is exposed to the slope so it will be more adversely affected by ambient air temperatures than the Stoughton system.

\subsubsection{Ground Conditions}

As both of these installations are horizontal ground loop configurations, the efficiencies were affected more by outdoor conditions (see Figure 14) than a vertical field loop would have been. The incoming fluid temperature from a vertical field loop would be more consistent throughout the year, as deeper ground temperatures vary less than ground temperatures $8 \mathrm{ft}$ below grade. A vertical loop would have likely maintained roughly a $50^{\circ} \mathrm{F}$ temperature year round, which would have resulted in steady state COPs closer to 3.6 for Black River Falls and 3.0 for Stoughton.

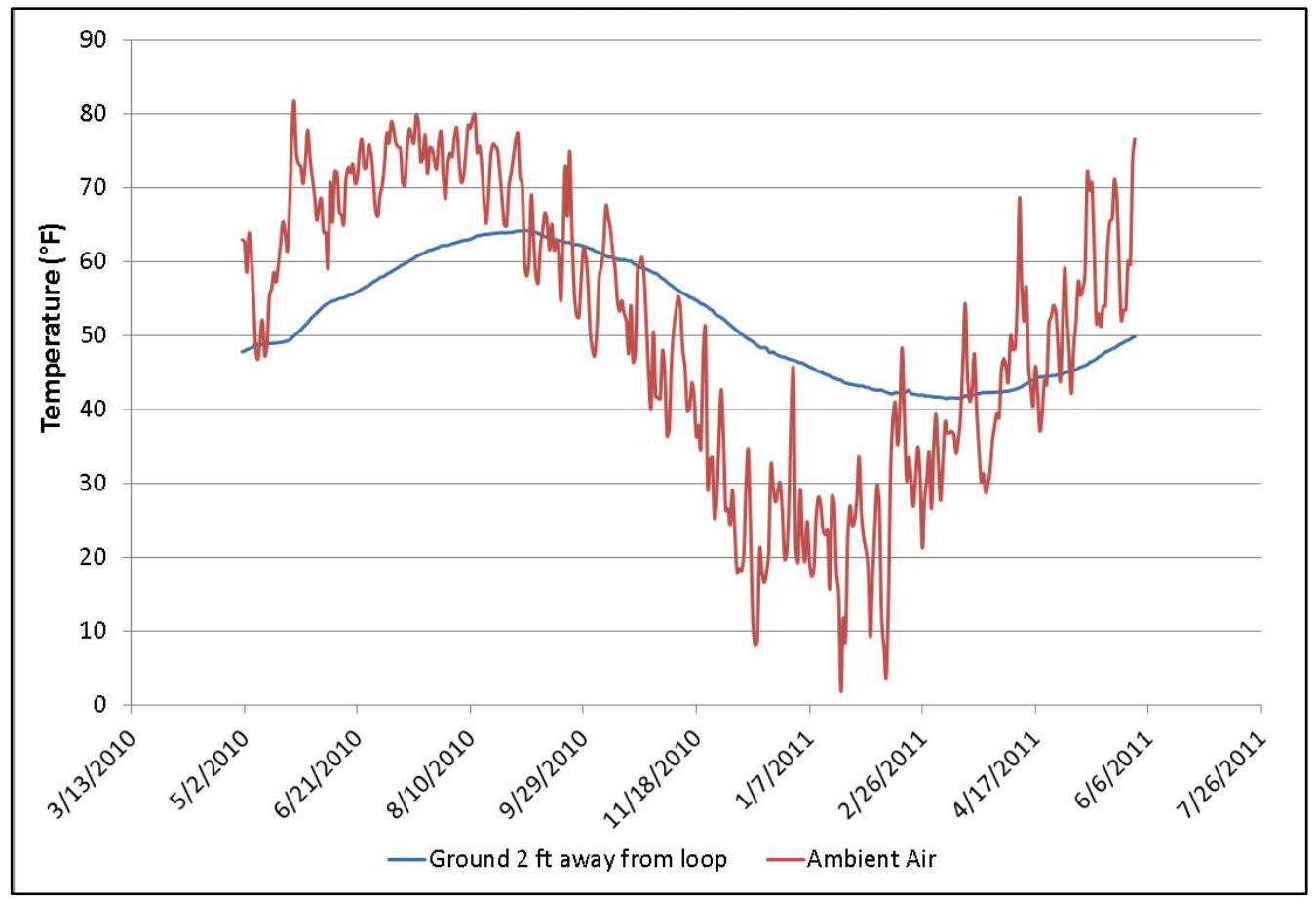

Figure 14. Mean daily ground temperature of the Stoughton home ground source field loop 


\subsubsection{Indoor Comfort}

Both homes were monitored to ensure that the GSHP was able to maintain the indoor temperature at desirable levels all year round. The Black River Falls home is a single-zone system; the Stoughton home has three zones.

During the summer, the indoor temperature of the Black River Falls home's main level was fairly consistently controlled at $75^{\circ} \mathrm{F}$ and never exceeded $78.5^{\circ} \mathrm{F}$. In the winter, the indoor temperature was maintained at $68^{\circ}-70^{\circ} \mathrm{F}$ and never dropped below $65^{\circ} \mathrm{F}$.

Over the summer, the Black River Falls homeowners expressed concern about what they perceived to be high relative humidity in their home. According to CARB's monitoring, there were periods during the 2009 summer when the relative humidity spiked to $67 \%$, but on average it was $55 \%$ for the summer months. This is at the upper end of the desirable humidity levels.

The sensible cooling load of this home is fairly small, so there is not a continuous call for cooling by the GSHP. This is the sole method of mechanical dehumidification designed into this home. The heat pump system is not required to run for extensive periods of time to address the sensible load, and therefore it is not able to adequately control the building's latent load. The use of a whole-house dehumidifier during the summer might be warranted to compensate for the minimal operation of the GSHP in cooling mode.

In addition, the Black River Falls homeowners open the windows and rear sliding doors in the summer to promote natural ventilation and cooling when outdoor conditions are suitable. The ERV was set up to provide whole-house mechanical ventilation without consideration for natural ventilation. The homeowners decided to turn off the ERV during the summer and found the home to be comfortable and the home was able to maintain relative humidity below $60 \%$.

CARB evaluated the HVAC design of the Stoughton home to ensure that it was rightsized, was optimized for efficiency, and would be able to maintain indoor comfort. Each floor (basement, first floor, and second floor) has its own zone. Comfort guidelines are provided in ACCA's Manual RS (ACCA 1997). The guide specifies comfort to be the ability to maintain an average floor-to-floor temperature difference of $2^{\circ} \mathrm{F}$ or less and a maximum floor-to-floor temperature difference of $4^{\circ} \mathrm{F}$ or less. Table 8 shows the monthly temperature variations between the first and second floors. Comparison to the basement was not made as the basement zone rarely called for cooling. The average temperature differential criteria are met for every month monitored. The maximum temperature differential criteria are nearly met. The few instances in which the maximum and minimum temperature differences exceeded $4^{\circ} \mathrm{F}$ were typically for less than 30 $\min$. 
Table 8 Floor-to-Floor Temperature Variations $\left(\Delta T=2^{\text {nd }}\right.$ Floor $-1^{\text {st }}$ Floor $)$

\begin{tabular}{|c|c|c|c|}
\hline Month & $\begin{array}{c}\text { Maximum } \Delta \mathbf{T} \\
\text { Between 1st and 2nd } \\
\text { Floors }\end{array}$ & $\begin{array}{c}\text { Minimum } \Delta \mathbf{T} \\
\text { Between 1st and } \\
\text { 2nd Floors }\end{array}$ & $\begin{array}{c}\text { Average } \Delta \mathbf{T} \\
\text { Between 1st and } \\
\text { 2nd Floors }\end{array}$ \\
\hline May 2010 & $1.8^{\circ} \mathrm{F}$ & $-2.0^{\circ} \mathrm{F}$ & $-0.4^{\circ} \mathrm{F}$ \\
\hline June 2010 & $1.4^{\circ} \mathrm{F}$ & $-1.6^{\circ} \mathrm{F}$ & $-0.2^{\circ} \mathrm{F}$ \\
\hline July 2010 & $1.8^{\circ} \mathrm{F}$ & $-2.0^{\circ} \mathrm{F}$ & $-0.1^{\circ} \mathrm{F}$ \\
\hline August 2010 & $2.0^{\circ} \mathrm{F}$ & $-1.7^{\circ} \mathrm{F}$ & $-0.3^{\circ} \mathrm{F}$ \\
\hline September 2010 & $1.4^{\circ} \mathrm{F}$ & $-2.3^{\circ} \mathrm{F}$ & $-0.9^{\circ} \mathrm{F}$ \\
\hline October 2010 & $1.2^{\circ} \mathrm{F}$ & $-2.6^{\circ} \mathrm{F}$ & $-1.0^{\circ} \mathrm{F}$ \\
\hline November 2010 & $-0.1^{\circ} \mathrm{F}$ & $-3.6^{\circ} \mathrm{F}$ & $-1.3^{\circ} \mathrm{F}$ \\
\hline December 2010 & $-0.2^{\circ} \mathrm{F}$ & $-4.6^{\circ} \mathrm{F}$ & $-1.8^{\circ} \mathrm{F}$ \\
\hline January 2011 & $-0.1^{\circ} \mathrm{F}$ & $-3.6^{\circ} \mathrm{F}$ & $-1.7^{\circ} \mathrm{F}$ \\
\hline February 2011 & $-0.1^{\circ} \mathrm{F}$ & $-4.3^{\circ} \mathrm{F}$ & $-1.9^{\circ} \mathrm{F}$ \\
\hline March 2011 & $4.4^{\circ} \mathrm{F}$ & $-4.3^{\circ} \mathrm{F}$ & $1.7^{\circ} \mathrm{F}$ \\
\hline April 2011 & $3.7^{\circ} \mathrm{F}$ & $-4.9^{\circ} \mathrm{F}$ & $-2.0^{\circ} \mathrm{F}$ \\
\hline May 2011 & $2.5^{\circ} \mathrm{F}$ & $-3.4^{\circ} \mathrm{F}$ & $-1.1^{\circ} \mathrm{F}$ \\
\hline June 2011 & $0.7^{\circ} \mathrm{F}$ & $-2.8^{\circ} \mathrm{F}$ & $-0.9^{\circ} \mathrm{F}$ \\
\hline Average & $\mathbf{1 . 5}^{\circ} \mathrm{F}$ & $-3.1^{\circ} \mathrm{F}$ & $-0^{\circ} \mathrm{F}$ \\
\hline
\end{tabular}

\subsubsection{Domestic Hot Water}

According to the 2000 Energy Center of Wisconsin's "Energy and Housing in Wisconsin" Study, $28 \%$ of homes have electric water heaters, and on average these homes use $3,250 \mathrm{kWh} / \mathrm{yr}$ to heat domestic water (Pigg and Nevius 2000). The Black River Falls and Stoughton homes used 775 and $2,159 \mathrm{kWh} / \mathrm{yr}$ of electricity annually to heat domestic water, respectively, which is a $76 \%$ and $34 \%$ reduction over a typical Wisconsin home.

The DHW systems in each home consists of a GSHP system, a desuperheater, and a DWHR system. The Black River Falls home has auxiliary electric backup; the Stoughton Home relies solely on a dedicated water-to-water GSHP. The 50-gal preheat tanks in both homes (see Figure 16) are fed by the main water line, which runs through DWHR units (see Figure 16) to capture some of the energy from hot water running down the drain. The preheat tank is connected to the space conditioning GSHP desuperheater via an internal heat exchanger. Schematic diagrams outlining the location of these systems are shown in Figure 17 and Figure 18. 


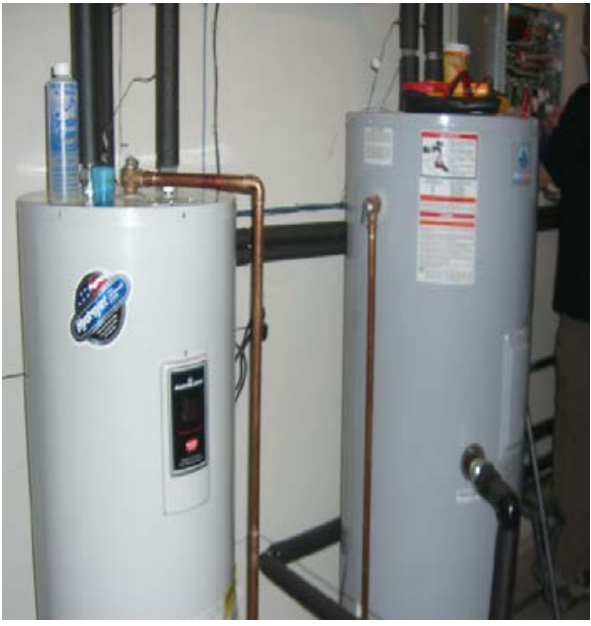

Figure 15. Buffer tank and storage tank in Stoughton home

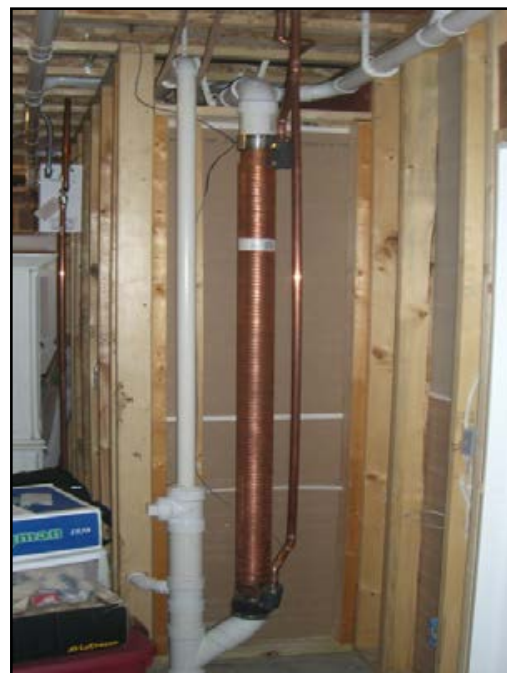

Figure 16. DWHR in Stoughton home

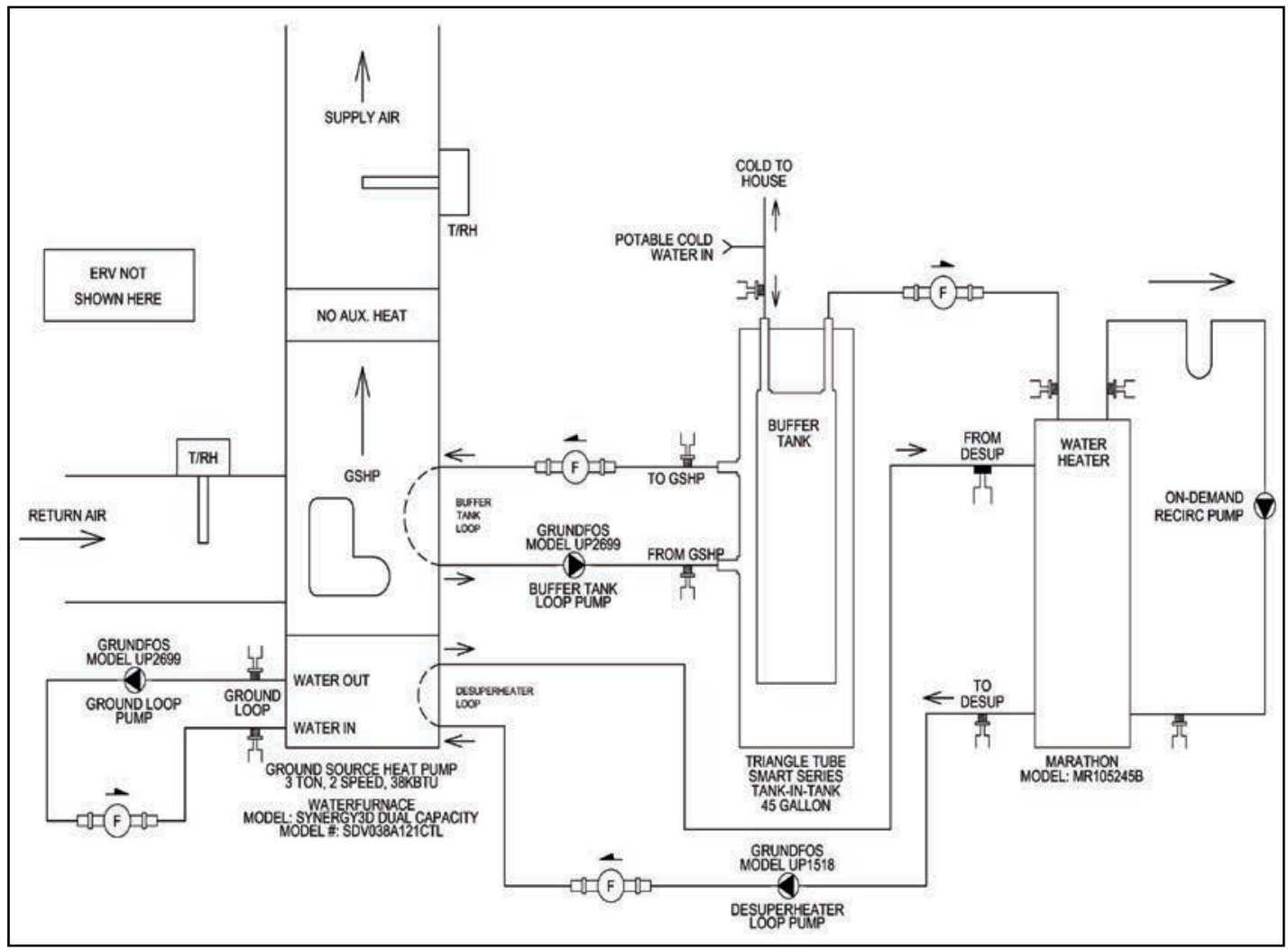

Figure 17. Schematic of GSHP/DHW systems at Black River Falls home 


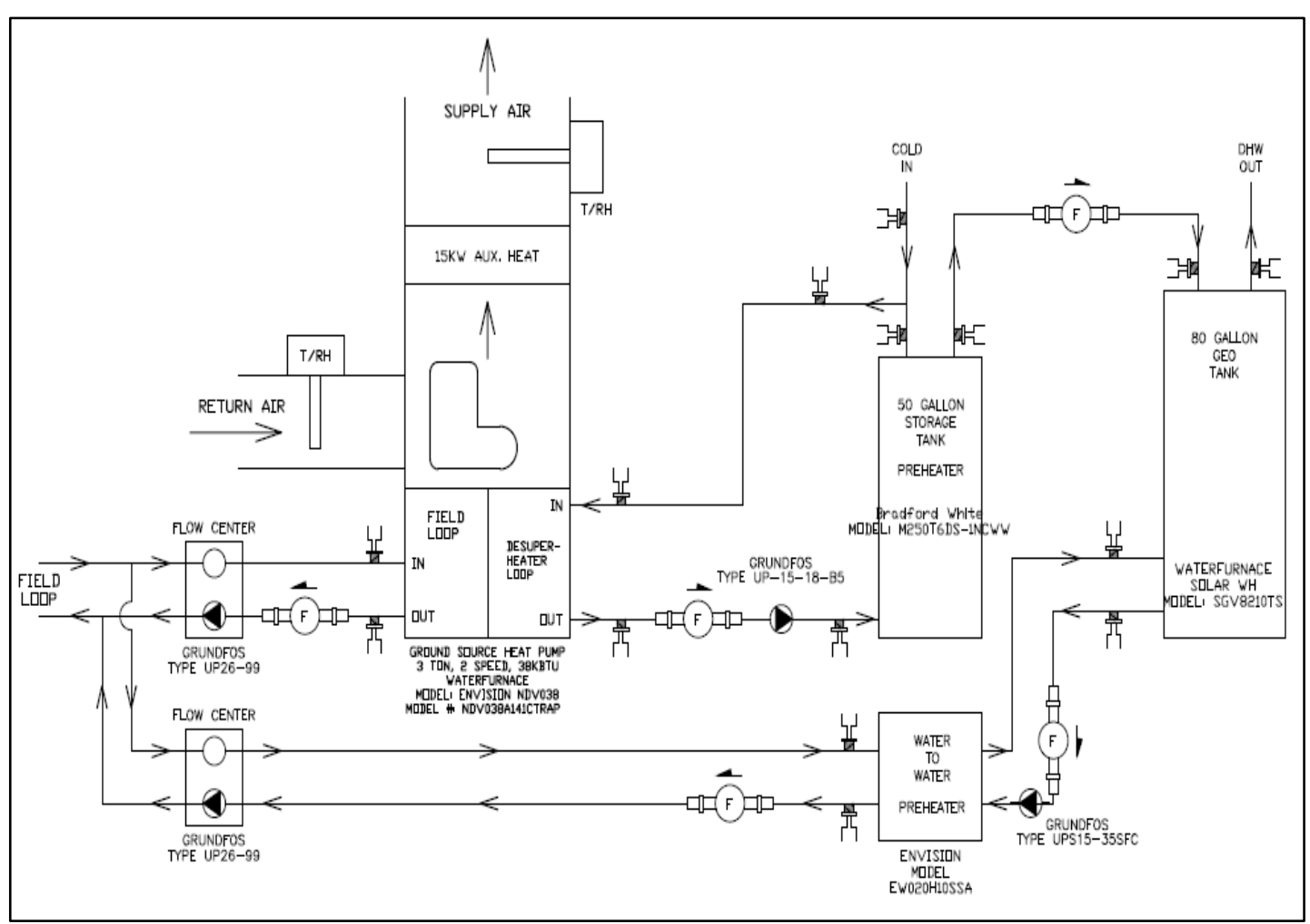

Figure 18. Schematic of GSHP/DHW systems at Stoughton home

Table 9 shows the calculated energy supplied by these additional sources and their overall contribution to the water heating. Standby heat losses of the storage tanks are not included. The Stoughton home uses significantly more energy for water heating (more energy was supplied, even though it has been monitored for roughly half the time period). This is anticipated with the higher occupancy of this home (three adults and a baby at the Stoughton home versus only two adults at the Black River Falls home).

Table 9. Water Heating Contribution by Source

\begin{tabular}{c|c|c|c|c}
\hline \multirow{2}{*}{$\begin{array}{c}\text { Water Heating } \\
\text { Source }\end{array}$} & \multicolumn{2}{|c|}{ Black River Falls } & \multicolumn{2}{c}{ Stoughton } \\
\cline { 2 - 5 } & $\begin{array}{c}\text { Average Annual } \\
\text { Energy Supplied } \\
\text { (MMBtu) }\end{array}$ & $\begin{array}{c}\text { DHW } \\
\text { Contribution }\end{array}$ & $\begin{array}{c}\text { Average Annual } \\
\text { Energy Supplied } \\
\text { (kBtu) }\end{array}$ & $\begin{array}{c}\text { DHW } \\
\text { Contribution }\end{array}$ \\
\hline Desuperheater & 5,751 & $61.6 \%$ & 5,541 & $32.5 \%$ \\
DHW GSHP & 1,397 & $15 \%$ & 9,654 & $56.6 \%$ \\
\hline DWHR & 530 & $5.7 \%$ & 1,863 & $10.9 \%$ \\
\hline $\begin{array}{c}\text { Electric Water } \\
\text { Heater Auxiliary }\end{array}$ & 1,652 & $17.7 \%$ & - & - \\
\hline Total & 9,330 & & 17,058 & \\
\hline
\end{tabular}

The average monthly measured COP of the Black River Falls and Stoughton DHW GSHP systems and the manufacturer-listed COP for those heat pumps only are shown in Figure 19 and Figure 20, respectively. 


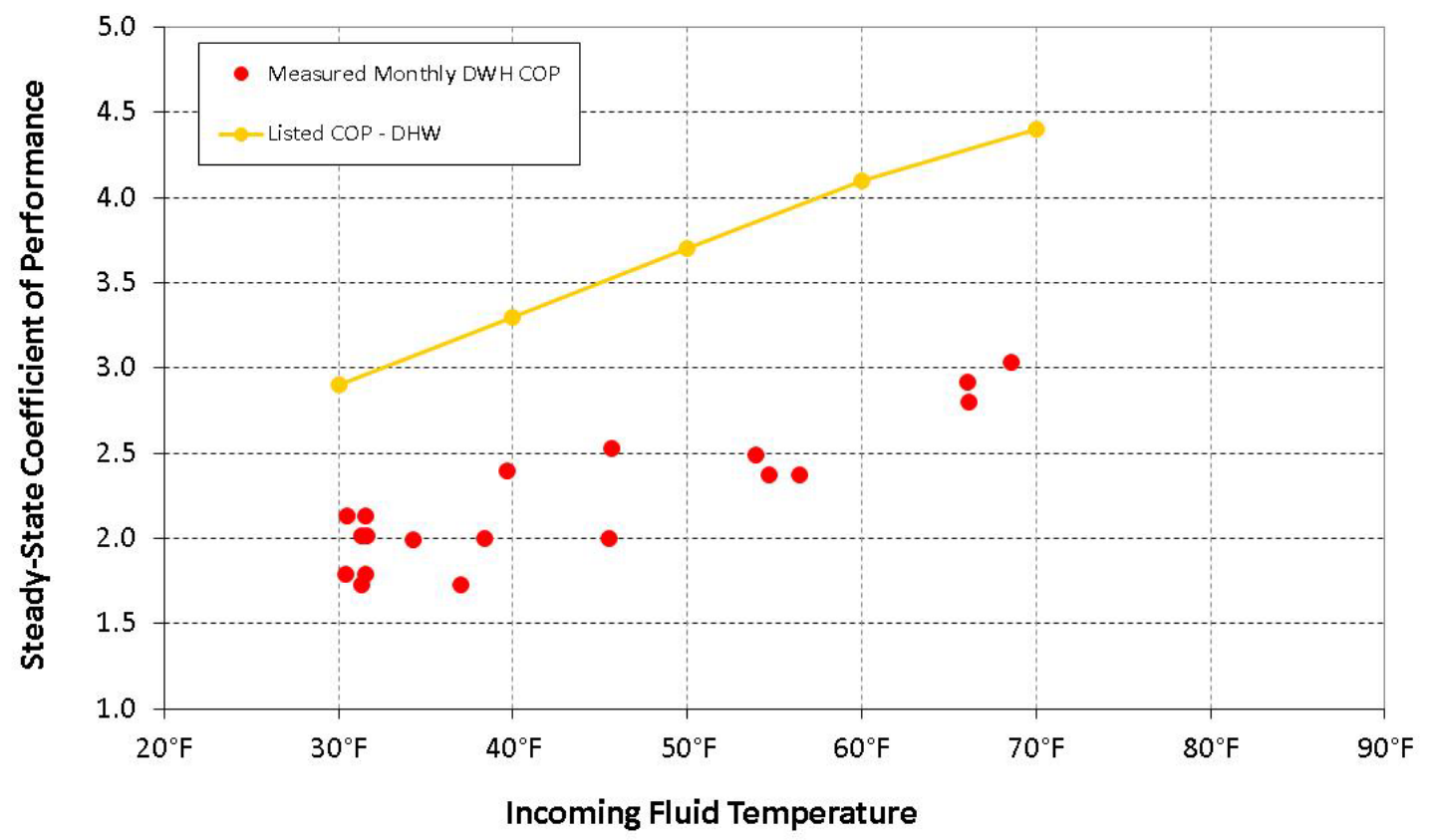

Figure 19. Measured versus literature COP of Black River Falls GSHP DHW mode

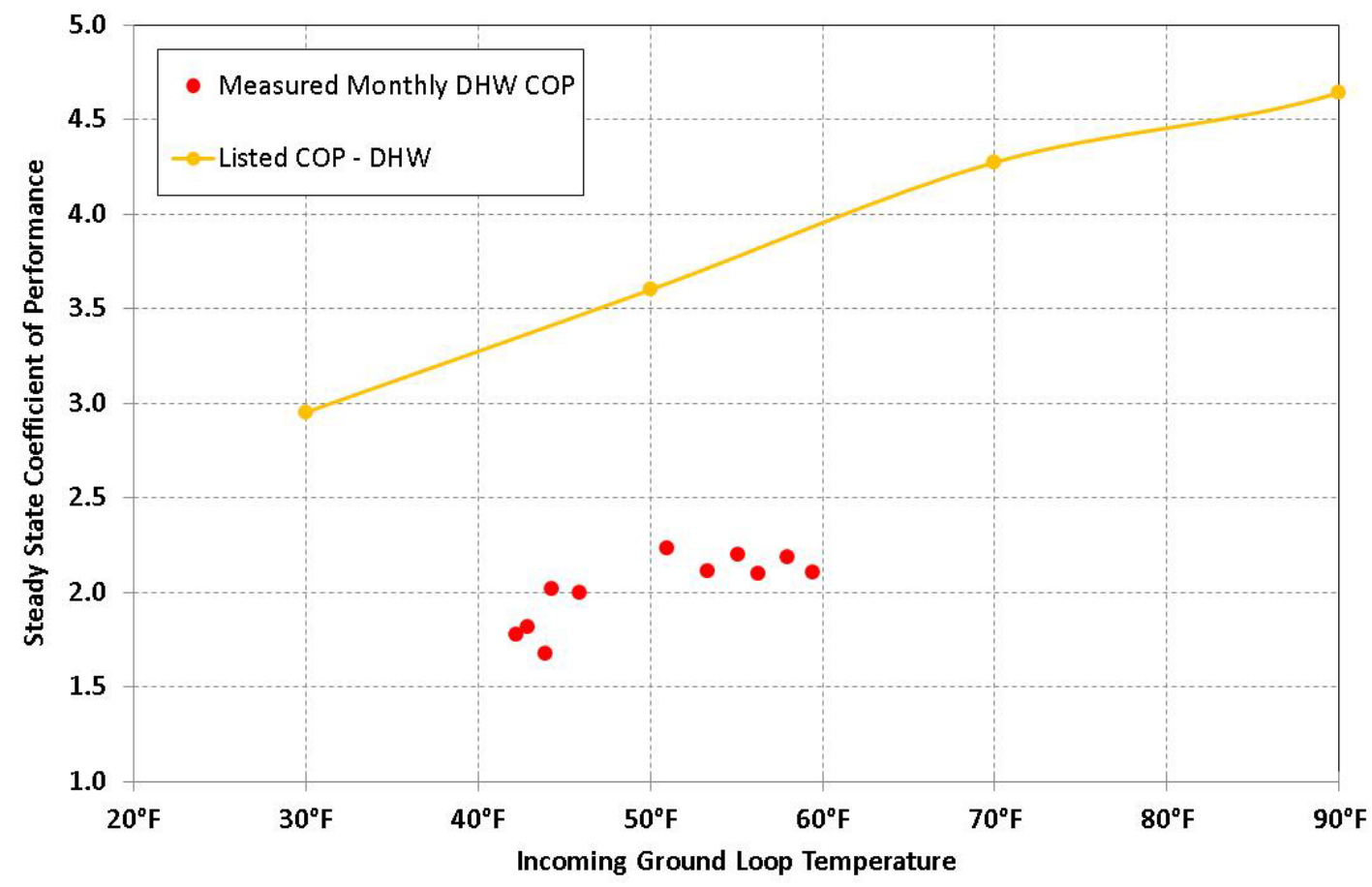

Figure 20. Measured versus literature COP of Stoughton DHW GSHP

Once again, the Synergy 3D GSHP is actually performing better in DHW mode (COP) than the system with higher rated efficiency, the dedicated Envision EW GSHP. The DHW COP for both systems is consistently lower than the rated performance. Regardless, the DHW mode is an efficient method to heat water compared to standard electric resistance water heating methods. In comparison to the recent heat pump water heaters that are on the market, the Stoughton system 
has a similar performance range and the Black River Falls system is slightly better (though it has an auxiliary electric resistance water heater to meet demand loads).

\subsubsection{Desuperheater}

A desuperheater is a secondary heat exchanger that captures some waste heat from the GSHP refrigerant line prior to rejecting to the ground. Typical operation of a desuperheater provides water preheating during cooling mode operation, but during heating mode, it "robs" potential heating capacity from the space conditioning. A reversing valve or smarter control logic (available in some newer GSHP models) is needed to avoid the space heating penalty, if this is of concern.

In the Black River Falls home, the desuperheater was directly plumbed to the water heater that has independent controls set to maintain DHW temperature at roughly $110^{\circ} \mathrm{F}$. In January, an on/off switch was installed on the desuperheater pump in case it needed to be shut off to optimize whole-house system performance (the homeowners have decided to not use the on/off switch seasonally). CARB recommends that the desuperheater be piped to a preheat tank (as was done at the Stoughton Home) and not directly to the auxiliary electric resistance water heater. This recommended configuration will allow for the maximum usable heat transfer from the desuperheater.

Figure 21 shows the daily heating contribution of the various components (electric water heater, DWHR, desuperheater, and buffer tank, which is directly supplied by the GSHP DHW mode) that heat water for the Chambers' home. Daily hot water use is also shown on the second y-axis. As noted in Figure 21, not all heat is delivered to the DHW as there are standby losses and an ondemand recirculation loop.

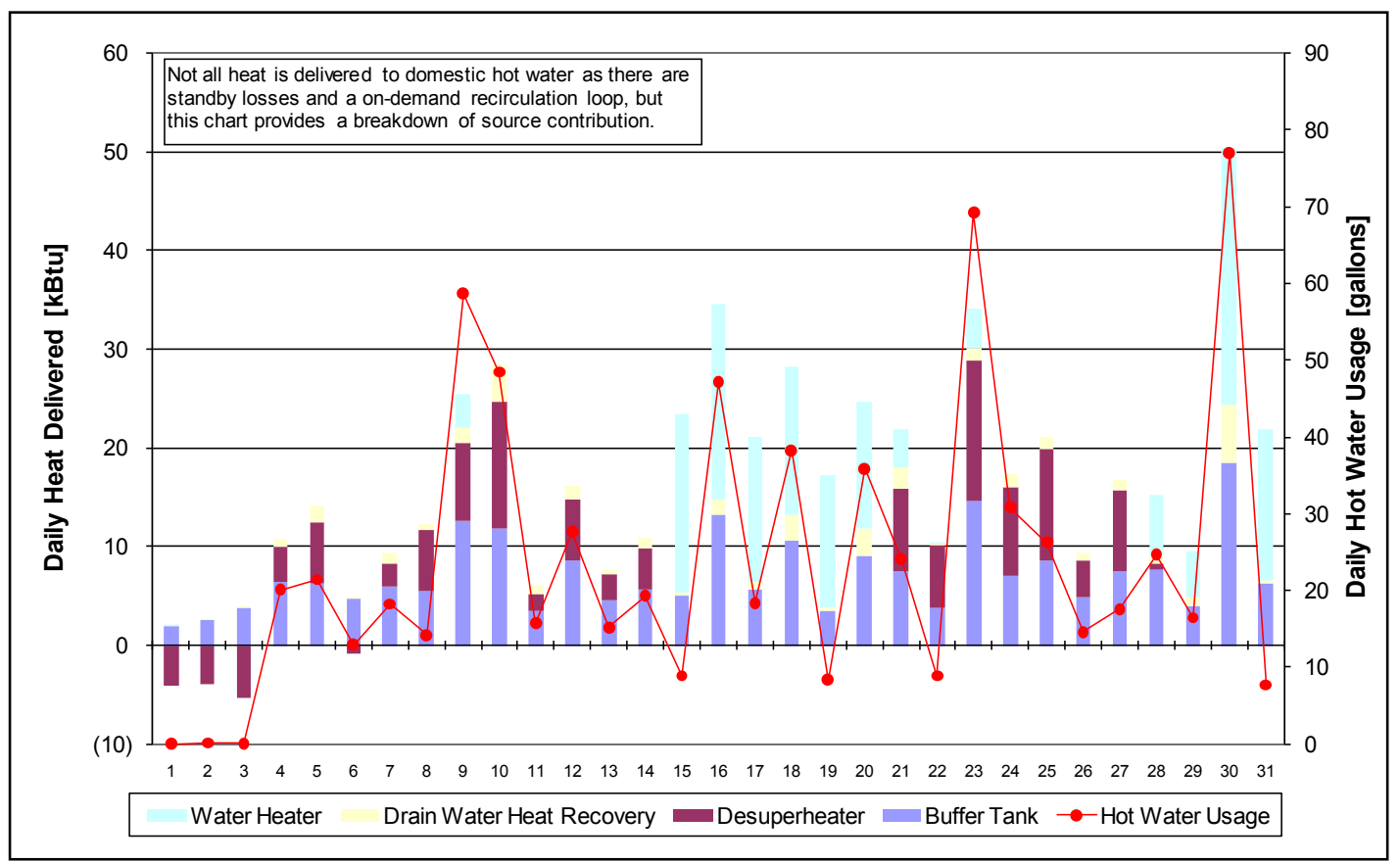

Figure 21. Water heating component breakdown for Black River Falls home in January 
In general, the desuperheater was acting as anticipated, essentially robbing heating capacity from the space conditioning to provide water heating during heating/DHW mode. During the coldest winter months, there is minimal operation of the electric resistance water heater.

When there was no demand for hot water and the GSHP was providing space heating (see the first three days of January), the desuperheater had a negative impact to water heating. As a result, the desuperheater was robbing heat from the water heater and increasing the heating capacity (the return temperature from the desuperheater loop was higher than the supply temperature during heating). Without any water demand, the primary tank temperature was not losing heat except for standby loss. At some point, the tank temperature was hot enough that the energy provided by the desuperheater was not useful and the desuperheater return temperature was actually returning hotter than it was leaving the GSHP. When there are draws for hot water, the tank temperature drops (from the cold incoming water) and the desuperheater once again is able to provide useful energy.

\subsubsection{Drain Water Heat Recovery}

The DWHR device in each home is a heat exchanger on the central waste drain that captures some heat from the hot water that goes down the drain and uses this energy to preheat cold water coming into the water heater.

The Black River Falls home used a R3-30 (3 pipes, 30 in. long) Power Pipe DWHR, which the manufacturer claims has a $32.9 \%$ heat exchange effectiveness at equal flow of $2.5 \mathrm{gpm}$. The Stoughton home used a R3-72 (3 pipes, 72 in. long) Power Pipe DWHR, which the manufacturer claims has a $58.5 \%$ heat exchange effectiveness at equal flow of $2.5 \mathrm{gpm}$.

As previously shown in Table 9, the Black River Falls and Stoughton DWHR units provided $5.7 \%$ and $10.9 \%$ of the overall water heating needed for these homes, respectively. The manufacturer advertises up to $35 \%$ hot water savings, but the performance of these units is heavily correlated to shower use. In addition, with the use of low flow showerheads and faucets, the 2.5 gpm equal flow conditions were not typically found in these homes. The homeowner's hot water draw patterns and use determine whether this technology is applicable to single-family residential projects. 


\section{Photovoltaic System Performance}

Each home uses a 5.76-kW solar PV system to harness the power of the sun. These systems consist of two pole-mounted 2.88-kW arrays of solar PV panels. The arrays are supported by dual-axis tracking systems that enable each to tilt and move, following the sun's position to convert as much sunlight as possible during the course of a day and season. These tracking systems can produce as much as 30\% more energy than a fixed-position system.

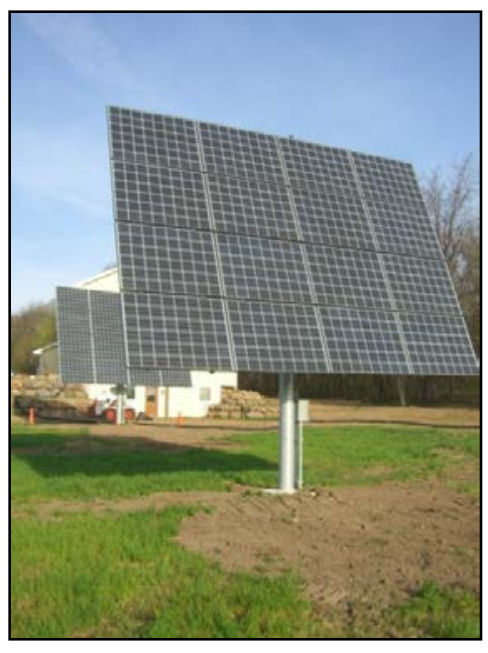

Figure 22. Stoughton PV system

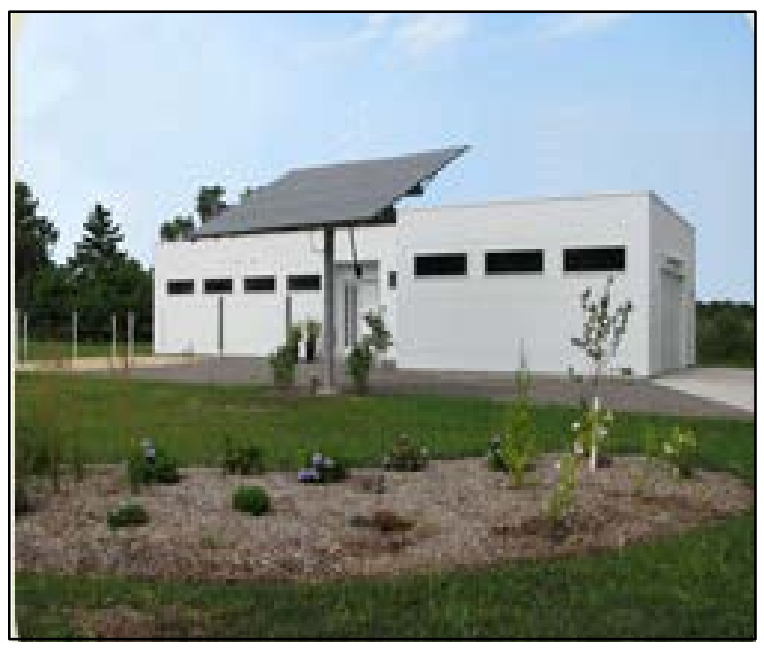

Figure 23. Black River Falls PV system

The actual PV generation tracked fairly consistent with the anticipated PV generation based on solar energy modeling. NREL PVWatts calculator was used to estimate the yearly solar energy output, assuming a direct current to alternating current derate factor of 0.83 . Typical Meteorological Year 2 files for Black River Falls and Stoughton are not available, so less accurate $40-\mathrm{km}$ monthly grid cell data published by NREL were used for each city. These data, which are based on measurements from 1961 to 1990, provide "monthly average daily total solar resource information on grid cells of approximately $40 \mathrm{~km}$ by $40 \mathrm{~km}$ " (NREL 2011). The results of the modeled PV generation versus actual generation are shown in Table 10. As previously mentioned in Section 2, the overall electricity generation of the Black River Falls home was lower than anticipated because a malfunctioning inverter resulted in minimal PV generation in January and February 2011.

Although the Stoughton home is significantly larger in floor area and volume, both homes were designed with the same PV generation capacity with a goal of being net zero. Post analysis by CARB determined that the Stoughton PV system was undersized based on the anticipated annual energy consumption of that home provided by the original rater. 
Table 10. PV System Performance Comparison to Modeled Values

\begin{tabular}{|c|c|c|c|c|c|c|}
\hline \multirow[b]{2}{*}{ Month } & \multicolumn{3}{|c|}{ Black River Falls } & \multicolumn{3}{|c|}{ Stoughton } \\
\hline & $\begin{array}{c}\text { Predicted } \\
\text { Solar } \\
\text { Radiation } \\
\text { (kWh } / \mathbf{m}^{2} \text {-day) }\end{array}$ & $\begin{array}{c}\text { Predicted } \\
\text { AC } \\
\text { Energy } \\
\text { (kWh) }\end{array}$ & $\begin{array}{c}\text { Actual } \\
\text { AC } \\
\text { Energy } \\
\text { (kWh)* }\end{array}$ & $\begin{array}{c}\text { Predicted } \\
\text { Solar } \\
\text { Radiation } \\
\left(\mathbf{k W h} / \mathbf{m}^{2} \text {-day) }\right.\end{array}$ & $\begin{array}{l}\text { Predicted } \\
\text { AC } \\
\text { Energy } \\
\text { (kWh) }\end{array}$ & $\begin{array}{l}\text { Actual } \\
\text { AC } \\
\text { Energy } \\
\text { (kWh) }\end{array}$ \\
\hline January & 4.14 & 654 & 437 & 3.72 & 590 & 627 \\
\hline February & 5.48 & 753 & 493 & 5.02 & 710 & 699 \\
\hline March & 5.97 & 901 & 962 & 5.35 & 810 & 742 \\
\hline April & 7.08 & 983 & 850 & 6.77 & 953 & 1,010 \\
\hline May & 7.94 & 1,117 & 737 & 7.55 & 1,071 & 1,218 \\
\hline June & 8.34 & 1,100 & 982 & 8.22 & 1,082 & 1,098 \\
\hline July & 8.28 & 1,119 & 1,127 & 7.96 & 1,067 & 1,259 \\
\hline August & 7.59 & 1,032 & 1,082 & 7.2 & 976 & 1,229 \\
\hline September & 6.33 & 849 & 850 & 6.11 & 820 & 962 \\
\hline October & 5.06 & 724 & 657 & 4.67 & 668 & 1,074 \\
\hline November & 3.32 & 484 & 558 & 3.07 & 435 & 651 \\
\hline December & 3.56 & 550 & 407 & 3.29 & 512 & 322 \\
\hline Year & 6.09 & 10,266 & 9,143 & 5.75 & 9,694 & 10,892 \\
\hline
\end{tabular}

* Average electricity generation over the two years of field monitoring. 


\section{Lighting, Appliances, and Miscellaneous Electric Loads}

LAMELs are often grouped together as the remaining contributors to the total home electricity demand after space heating, space cooling, DHW, and ventilation. LAMELs are heavily dependent on occupant use, and several studies have attempted to measure the use patterns and quantity of LAMEL electricity use. Unfortunately, these studies cannot replace the high-quality data obtained through extensive monitoring. The TIAX U.S. Residential Information Technology Energy Consumption in the 2005 and 2010 Report is the most thorough information on items that make up LAMELs (Roth et al. 2006), but the usage patterns are calculated based on equations and not specifically monitored. Some studies, such as RECS (EIA 2005), estimate use patterns through surveys, but respondents may believe their uses are different than actual monitored data.

The BA HSP, part of the Benchmark, stipulate the quantity of yearly energy use from LAMELs as well as the use patterns for these loads based on various other studies. The B10 HSP includes appliances that are in compliance with "the federal appliance standards in effect as of January 1 , 2010, and lighting characteristics and miscellaneous electric loads most common in 2010" (Hendron and Engebrecth 2010). The two houses evaluated here, however, were constructed with all ENERGY STAR appliances and high-efficacy lighting. Therefore, these houses should show savings over the B10 Benchmark in lighting and appliances, but not necessarily in MELs, which are more difficult to predict and control. Unfortunately, a completely direct comparison between the BA HSP and the two test homes cannot be made because component loads in the test homes were not disaggregated in the same manner as the BA HSP.

The measured component load breakdowns of the Black River Falls and Stoughton LAMELs are shown in Figure 24 and Figure 25, respectively. The major categories are appliances, lights, and MELs. MELs have a subcategory of Outlets and Other MELs. A more detailed breakdown of those categories is provided by end load where data are available with the lighter shade of the primary categories.

In the Black River Falls home, the lighting in the master suite and the outlets in the living room were the major sources of electricity use for these two major components. The outlets in the living room comprise the home entertainment center, so it is not surprising that this represents more than half the outlet loads.

The major appliances account for approximately $40 \%$ of the electricity consumption in the two test homes outside of heating, cooling, and hot water. These are all top-of-the-line units (ENERGY STAR labeled, if available), so little can currently be done from a technology standpoint to reduce this use. The same is true of the lighting, which is nearly all compact fluorescent or LED lighting. Essentially, the homeowners would need to alter their behavior to see a significant reduction in the lighting and appliance portion of their LAMELs consumption. 


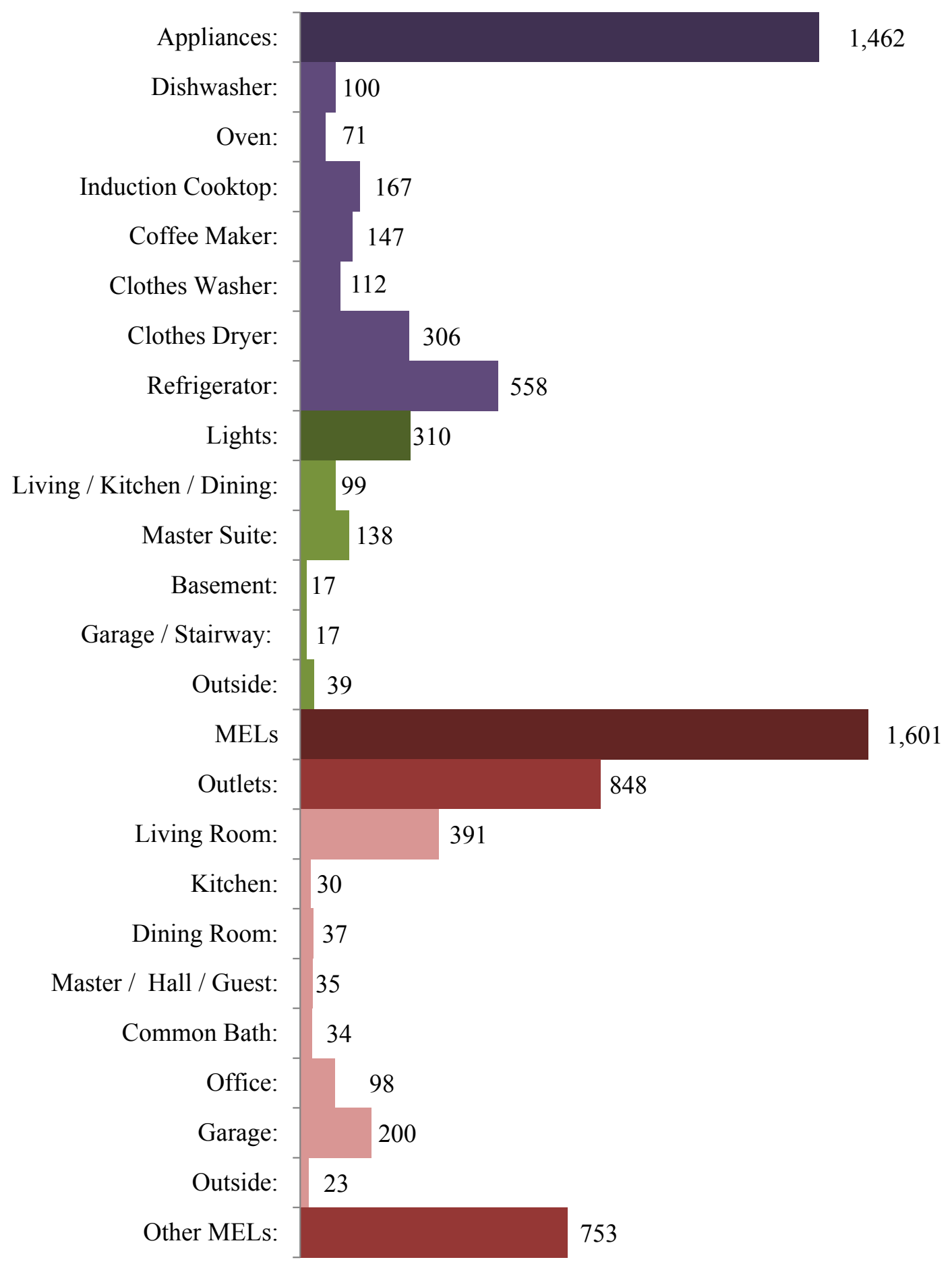

Figure 24. Black River Falls LAMEL breakdown (kWh/yr)

Lighter shades are subcomponents of darker shades of the same color. 


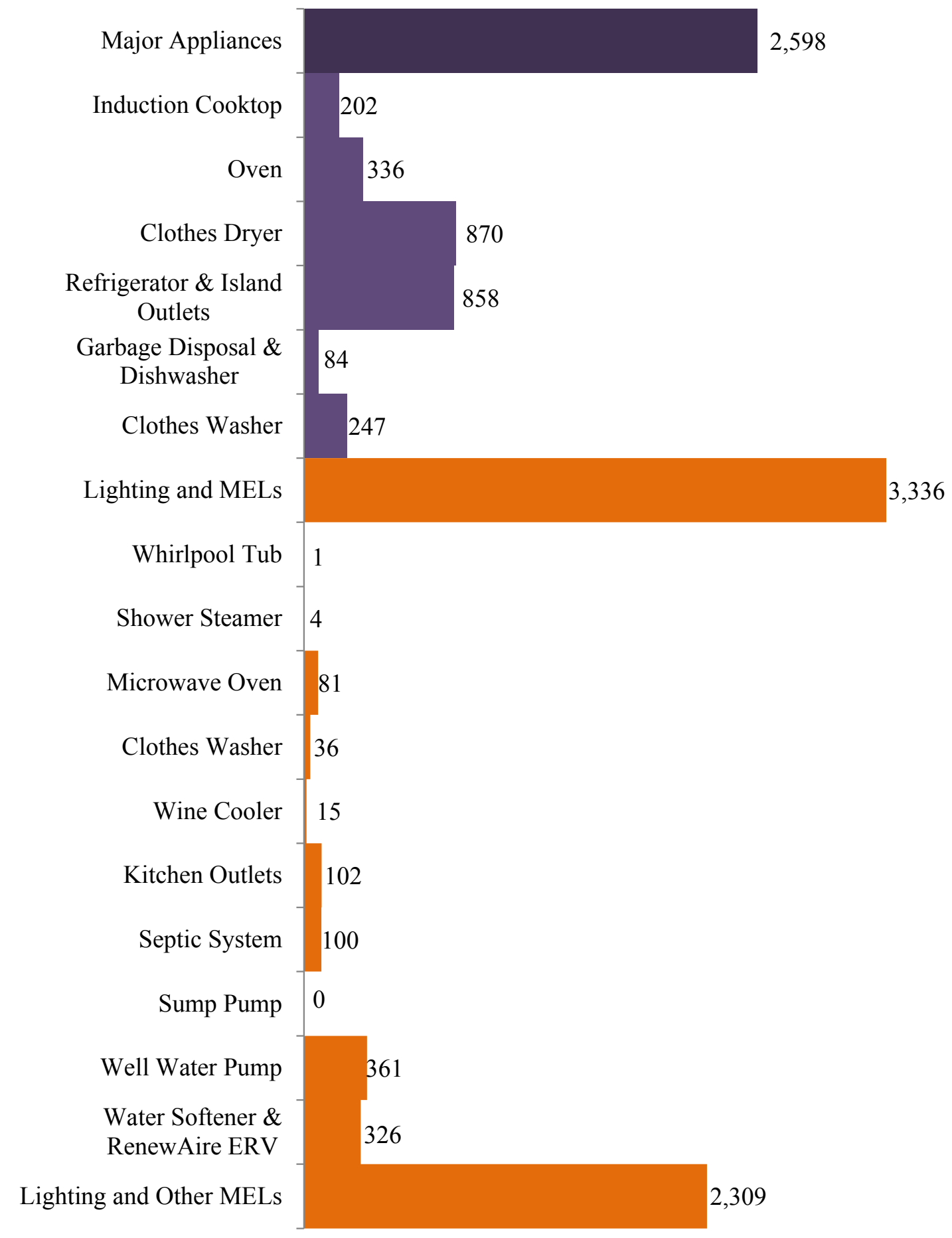

Figure 25. Stoughton LAMEL breakdown (kWh/yr)

Lighter shades are subcomponents of darker shades of the same color. 


\subsection{Lighting}

In the BA HSP, the lighting loads are separated into four categories: interior hard-wired lighting, interior plug-in lighting, garage lighting, and exterior lighting. The yearly electricity consumption and lighting profiles can be defined using two methods. The more complicated Option 2 calculates the yearly loads and hourly load profile based on a room-by-room calculation. The simpler Option 1, which is the basis for comparison in this report and the method implemented in BEopt, defines the yearly loads as a function of finished floor area (FFA) or garage area, which is measured in square feet, as shown in Equations (6) through (9). These equations are meant to approximate a house with a lighting breakdown of $66 \%$ incandescent, $21 \%$ compact fluorescent, and 13\% T-8 linear fluorescent.

$$
\begin{array}{lll}
\text { Interior hard-wired lighting } & =0.8 \times(\mathrm{FFA} \times 0.542+334) \mathrm{kWh} / \mathrm{yr} \\
\text { Interior plug-in lighting } & =0.2 \times(\mathrm{FFA} \times 0.542+334) \mathrm{kWh} / \mathrm{yr} \\
\text { Garage lighting } & =\text { Garage Area } \times 0.08+8 & \mathrm{kWh} / \mathrm{yr} \\
\text { Exterior lighting } & =\mathrm{FFA} \times 0.145 & \mathrm{kWh} / \mathrm{yr}
\end{array}
$$

The lighting electricity consumption for the Black River Falls home was measured individually for interior hard-wired lighting, garage lighting, and exterior lighting. The interior plug-in lighting is included in the outlet electricity consumption because outlet loads could not be separated by end use. The categorization of plug-in lighting is similar to other categorizations, where plug-in lighting is considered a miscellaneous electric load. Unfortunately, the lighting electricity consumption could not be monitored separately in the Stoughton home because the electrical panel was installed and configured prior to CARB's input on how to zone the breakers.

A comparison of the yearly lighting electricity use between the Black River Falls home and the BA HSP values for a similarly sized home is shown in Table 11. The Black River Falls home shows a tremendous savings in lighting energy over the BA HSP. These savings are mostly due to the installation of high-efficiency lamps, but may have been influenced by differing use patterns at the home than predicted by the protocols.

Table 11. Annual Lighting Electric Use Comparison at the Black River Falls Home (kWh/yr)

\begin{tabular}{c|c|c}
\hline Appliance & BA HSP & Black River Falls \\
\hline Interior Hard-Wired & 1,287 & 271 \\
\hline Interior Plug-in & 321 & N/A \\
Garage & 52 & 17 \\
\hline Exterior & 341 & 39 \\
\hline
\end{tabular}

In the HSP, lighting use over the course of the year is determined using normalized hourly lighting profiles for each month of the year. These profiles are defined in the BA Analysis Spreadsheet for Option 1. A comparison between the stipulated profiles and the measured load profiles of the Black River Falls home is shown in Figure 26. The profiles show remarkable correlations, but the morning lighting loads are somewhat underestimated. 

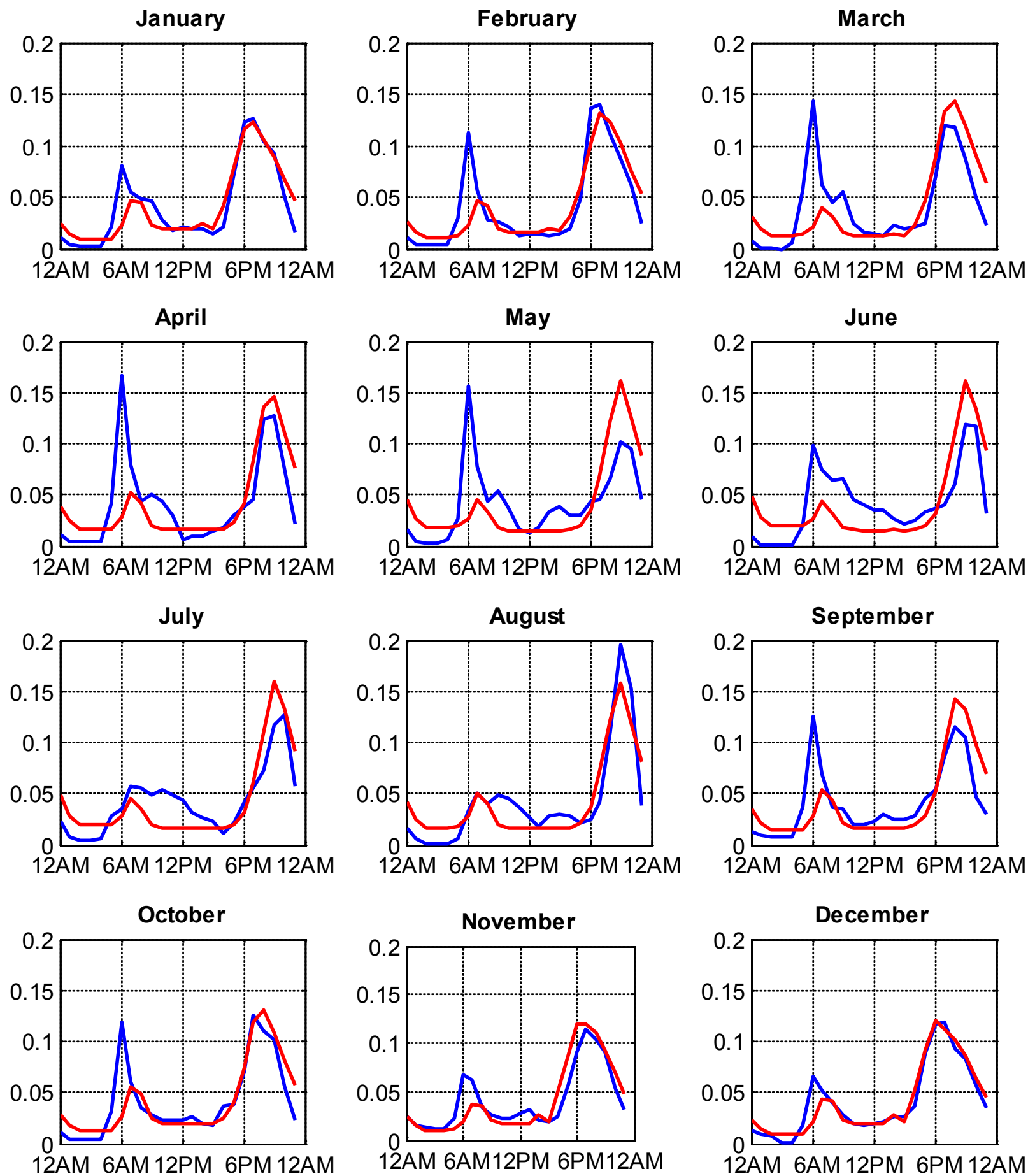

Black River Falls Home

BA Simulation Protocols

Figure 26. Normalized hourly lighting profile comparison (Black River Falls)

Although the lighting schedules in the HSP do not correct for geographic differences in the amount of light over the course of the day or year, the geography of the home does not seem to be a factor in the discrepancy between the HSP and the Black River Falls lighting profiles. Located in a northern climate, these homes experience less sunlight in the winter and more 
sunlight in the summer than the average American home. However, there is no clear pattern between morning lighting intensity and month of the year in the Black River Falls home.

Instead, the discrepancy may be due to the residents waking up earlier than the "average" American approximated by the protocol. The Black River Falls home sees a peak in lighting energy during the 6:00 a.m. hour, whereas the HSP profiles predicts a peak during the 7:00 a.m. hour. This suggests that the HSP expects residents to wake up during the 7:00 a.m. hour, but the Black River Falls residents wake up during the 6:00 a.m. hour. There is more light during the 7:00 a.m. hour, so the residents use more energy during the morning because they start the day earlier.

\subsection{Appliances}

In the BA HSP, major appliance loads are defined as the electricity and gas loads from the refrigerator, clothes washer, clothes dryer, dishwasher, and oven/range. The annual electricity loads are defined as a function of the number of bedrooms $\left(\mathrm{N}_{\mathrm{br}}\right)$. The forumlas for these loads in all-electric homes in $\mathrm{kWh} / \mathrm{yr}$ are shown in Equations (10) through (14).

$\begin{array}{llll}\text { Clothes Washer } & = & 38.8+12.9 \times \mathrm{N}_{\mathrm{br}} & \mathrm{kWh} / \mathrm{yr} \\ \text { Dishwasher } & = & 87.6+29.2 \times \mathrm{N}_{\mathrm{br}} & \mathrm{kWh} / \mathrm{yr} \\ \text { Refrigerator } & = & 434 & \mathrm{kWh} / \mathrm{yr} \\ \text { Clothes Dryer } & = & 538.2+179.4 \times \mathrm{Nbr} & \mathrm{kWh} / \mathrm{yr} \\ \text { Oven/Range } & = & 250+83 \times \mathrm{N}_{\mathrm{br}} & \mathrm{kWh} / \mathrm{yr}\end{array}$

A comparison between the yearly major appliance electricity use of the HSP Benchmark and the Black River Falls and Stoughton homes is shown in Table 12. These homes use less energy than the BA HSP predicts because of high-efficiency appliances. Use patterns may also be a factor, but the impact on use is not easily determined.

Table 12. Yearly Major Appliance Electric Use Comparison (kWh/yr)

\begin{tabular}{c|c|c|c|c}
\hline Appliance & $\begin{array}{c}\text { BA HSP } \\
\text { (3-BR) }\end{array}$ & $\begin{array}{c}\text { Black } \\
\text { River Falls }\end{array}$ & $\begin{array}{c}\text { BA HSP } \\
\text { (5 BR) }\end{array}$ & Stoughton \\
\hline Clothes Washer & 77.5 & 112 & 103.3 & 247 \\
\hline Dishwasher & 175.2 & 100 & 233.6 & 84 \\
\hline Refrigerator & 434 & 558 & 434 & N/A \\
\hline Clothes Dryer & $1,076.4$ & 306 & $1,435.2$ & 870 \\
Range/Oven & 499 & 238 & 665 & 538 \\
\hline
\end{tabular}

Unlike lighting, The BA HSP defines the use of major appliances and MELs by an hourly normalized energy use profile and a monthly seasonal multiplier. The BA HSP hourly and monthly profiles are compared to the equivalent profiles measured at the two test homes in Figure 27 and Figure 28. Again, the BA HSP hourly and monthly profiles show remarkable correlations to the measured loads at the two test homes. 
Clothes Washer
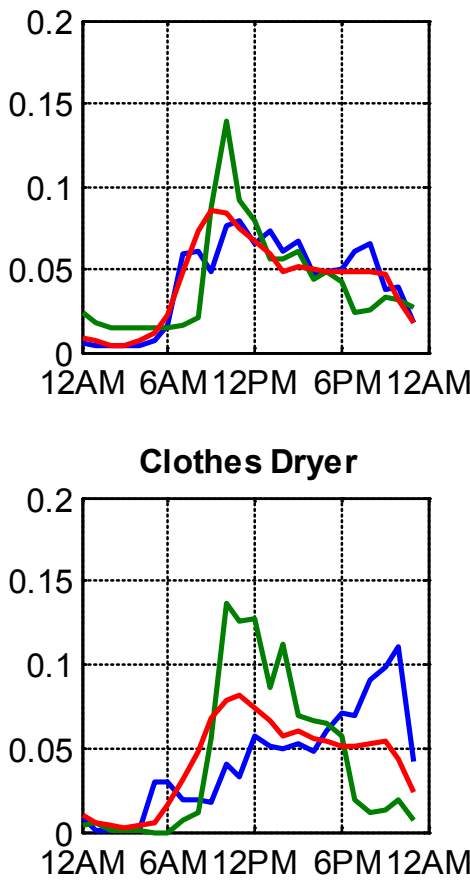

Dishwasher

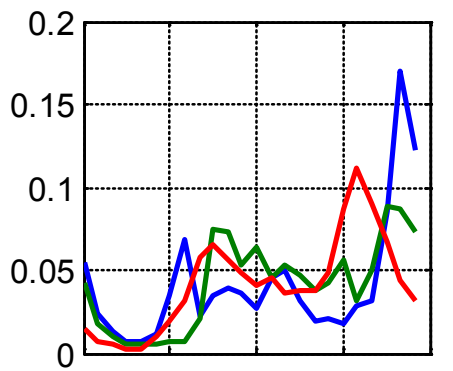

12AM 6AM12PM 6PM12AM

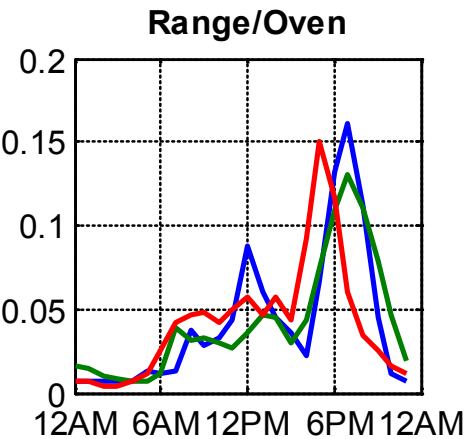

Refrigerator

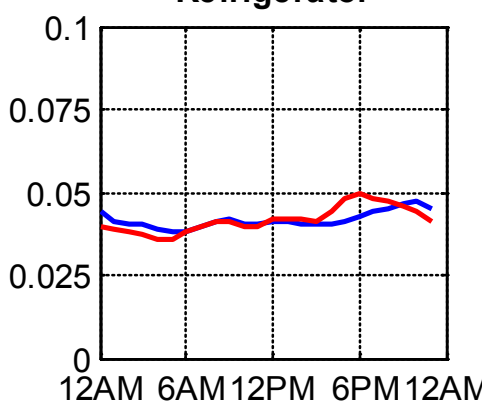

- Black River Falls Home
Stoughton Home
BA Simulation Protocols

Figure 27. Hourly normalized energy use profile comparison for major appliances
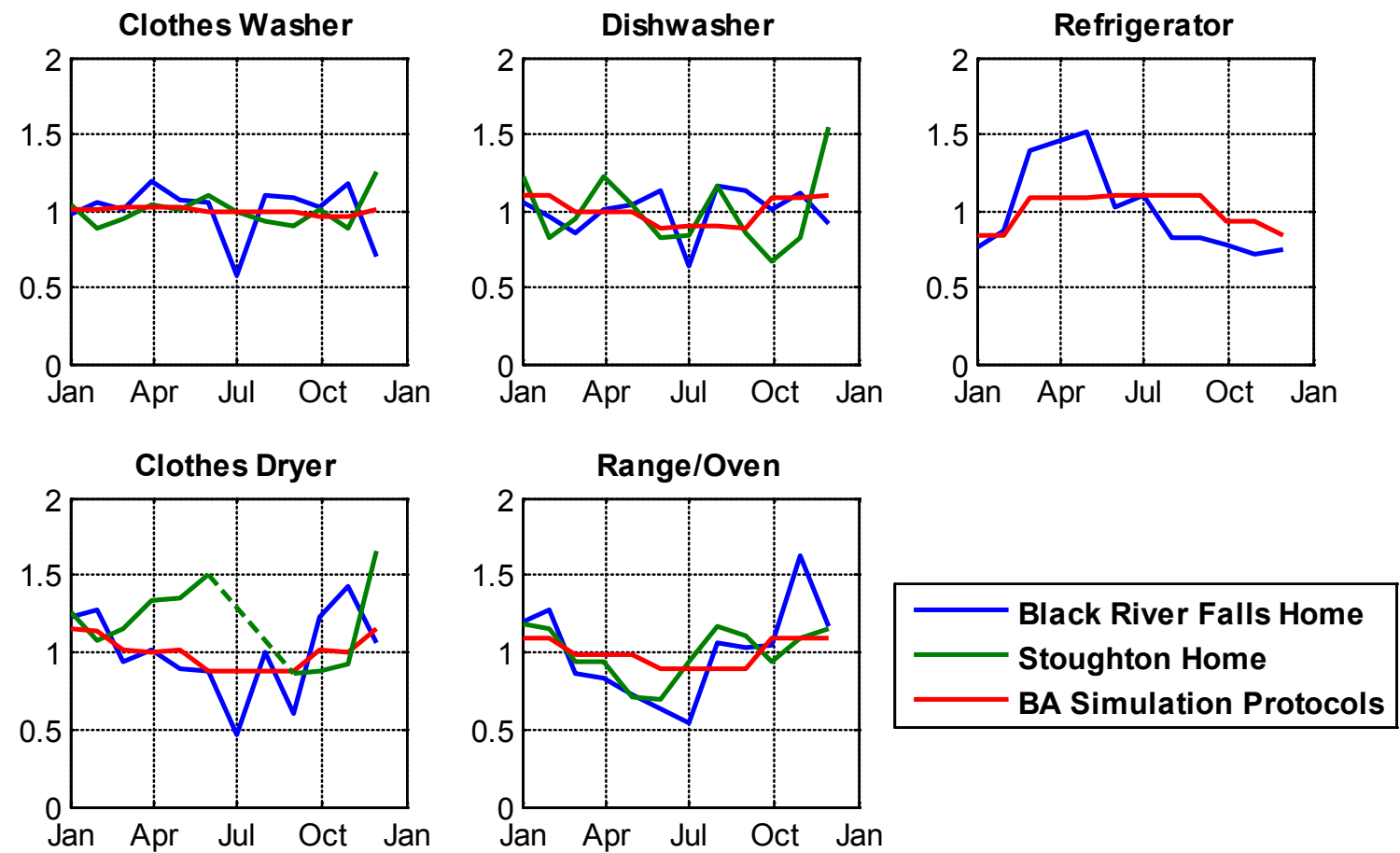

Figure 28. Monthly seasonal multipliers comparison for major appliances ${ }^{1}$

\footnotetext{
${ }^{1}$ There are no data for July and August for the clothes dryer at the Stoughton Home. Data are shown as a dotted line. The Stoughton refrigerator could not be isolated as it included the kitchen island outlets on the same breaker.
} 


\subsection{Miscellaneous Electric Loads}

The BA HSP hourly and monthly profiles for selected MELs are compared to the equivalent profiles measured at the two test homes in Figure 29 and Figure 30, respectively. Only some MELs were monitored directly in the test homes. Therefore, these graphs are selective and exclude many of the measured MELs in the HSP. Furthermore, the plug-in lighting energy is included in the total MEL numbers for the Black River Falls home, which may explain the discrepancy between the BA HSP profile and the measured values. Again, the BA HSP hourly and monthly profiles show remarkable accuracy to the measured loads at the two test homes.

For the Black River Falls and Stoughton homes, the cooking appliances are considered to be the sum of the electricity measured at the kitchen outlets, range hood, coffee maker, and microwave. At the Black River Falls home, the microwave is measured on the same breaker as the oven and is not included in the cooking appliances. The MEL refrigerator is the sum of the electricity measured at the wine cooler and the beer refrigerator. The total MELs cannot be graphed for the Stoughton home because the lighting and MELs are measured as a combined value.
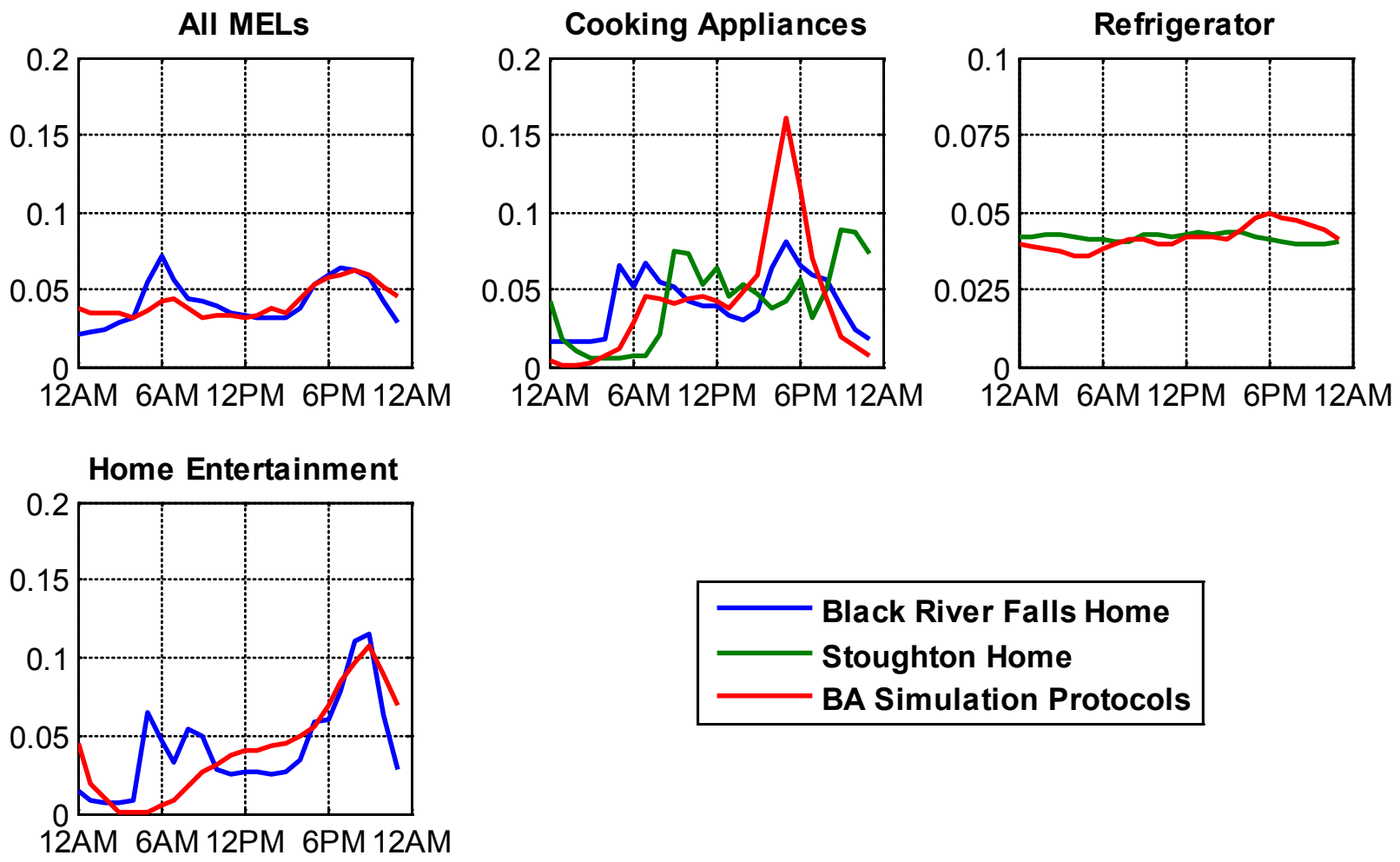

Figure 29. Hourly normalized energy use profile comparison for MELs 

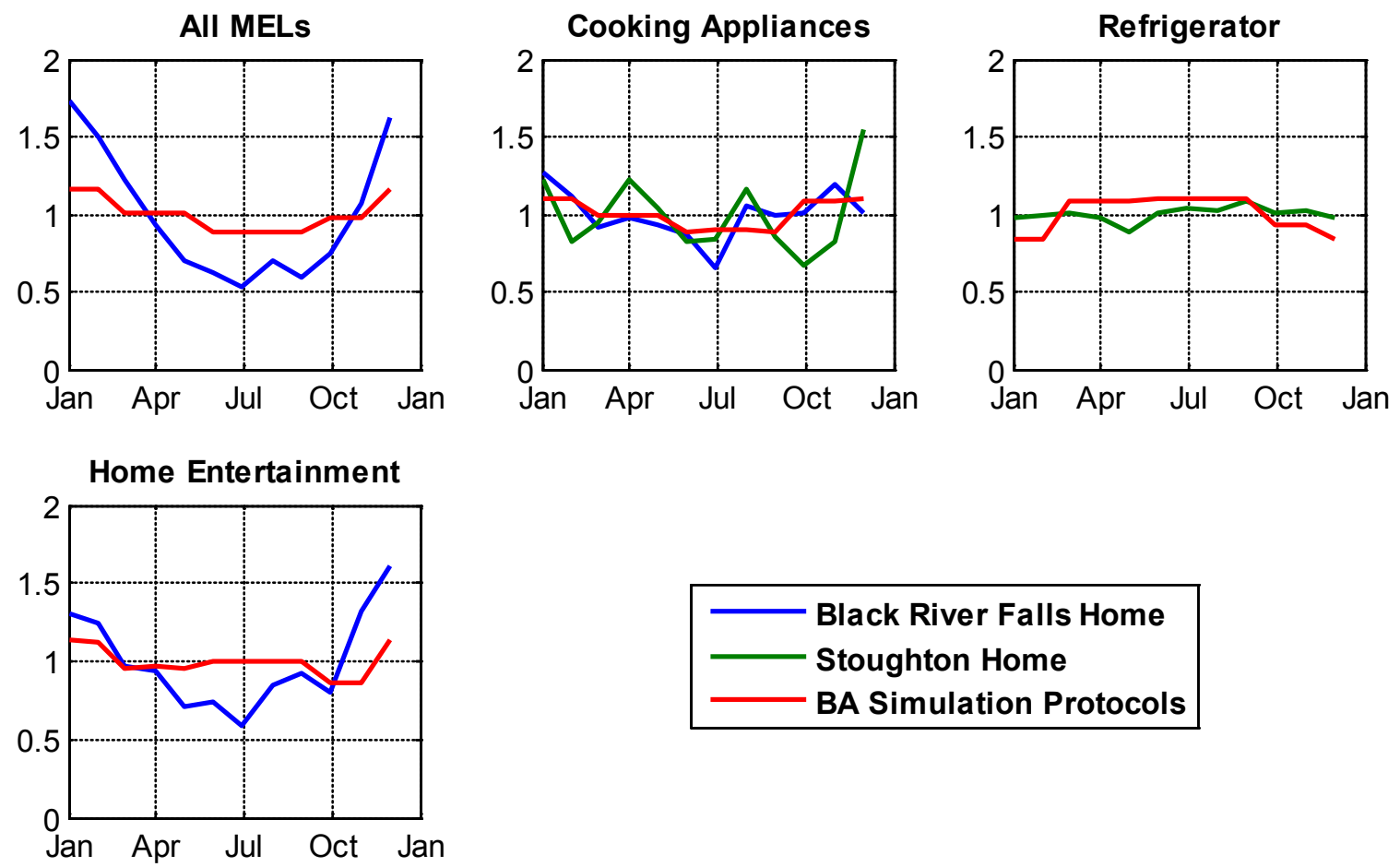

Figure 30. Monthly seasonal multipliers comparison for MELs

\subsubsection{Standby Energy Use}

During July 2009 the homeowners at the Black River Falls home were not home, which provided an opportunity to measure the standby energy use. Although the homeowners at the Stoughton home were not out of town during a similar period of time, there are days throughout the year that provide an opportunity to determine standby energy use. The Black River Falls and Stoughton homes have a daily standby energy use of 412 and $375 \mathrm{Wh} /$ day, respectively, when looking at the dishwasher, oven, cooktop, coffee maker, clothes washer, clothes dryer, and microwave. Assuming an electricity rate of $\$ 0.10 / \mathrm{kWh}$ this standby energy amounts to an additional $\$ 15.03 / y r$ and $\$ 13.69 / y r$, respectively, for the appliances.

Table 13. Daily Standby Energy Use (Wh)

\begin{tabular}{c|c|c}
\hline Appliance & Black River Falls & Stoughton \\
\hline Dishwasher & 37 & 25 \\
Oven & 5 & 155 \\
Cooktop & 190 & 27 \\
Coffee Maker & 155 & - \\
Clothes Washer & 25 & 35 \\
Clothes Dryer & 0 & 0 \\
Microwave & N/A & 133 \\
\hline
\end{tabular}

In terms of the lighting and outlets, the only consistent standby energy use was from the garage outlets at the Black River Falls home. This circuit breaker averages $133 \mathrm{Wh}$ /day (roughly $5 \mathrm{~W}$ ) when there was no home occupancy. After some investigation, it was determined that the home security system is wired into the garage electrical circuit. 


\section{Conclusions}

These two test home evaluations provided valuable data about the true in-field performance of various building mechanical systems and LAMELs. In addition, this information, though a small sample set, helps to validate the BA HSP homeowner use patterns. Answers to the other research questions are:

- What is the installed system efficiency of these GSHPs? How do these differ from the units' rated efficiency?

The steady-state heating COP for low and high stage operation of the Black River Falls GSHP system was 3.1, which is $31 \%$ and $23 \%$ less than the rated unit efficiency, respectively. The steady-state cooling EER for the low stage was 18.1 and for the high stage was 15.9 , which is $23 \%$ and $14 \%$ less than the rated unit's efficiency, respectively.

The steady-state heating COP for low and high stage operation of the Stoughton GSHP system was 2.7 , which is $47 \%$ and $36 \%$ less than the rated unit efficiency, respectively. The steady-state cooling EER for the low stage was 16.7, which is $44 \%$ less than the rated unit efficiency. This system rarely operated in high-stage cooling mode.

The differences between the rated and measured system efficiencies are caused in large part by the ground loop and desuperheater pump energy in the efficiency calculations and the added fan power from the inclusion of a full duct system connected to the GSHP. These items are not accounted for (or not fully accounted for) in the rated unit efficiencies.

- How effective are GSHPs in providing DHW?

These two variations in GSHP water heating (three-mode GSHP and dedicated DHW GSHP) provided COPs of 1.5-3.0. Though highly efficient, heat pump water heaters can provide water heating efficiencies of 1.5-2.5 at a significantly lower first cost. In the case of the Black River Falls GSHP, this third mode was just an add-on benefit to the space conditioning system. For the Stoughton home, the inclusion of a dedicated GSHP just for water heating was not cost effective and resulted in greater ground loop pumping being associated with the space conditioning GSHP.

- Is DWHR effective in single-family homes? What are the major drivers in its performance?

For the more standard length DWHR unit (72-in. unit at the Stoughton home), a 10\% DHW saving is good for a passive system. As overall water use is not high at these homes, the cost benefit of this system is minimal. These units are largely dependent on shower use, so the systems will likely have greater benefits in multifamily housing.

- What are the major contributors to LAMELs in these homes?

Though the 2005 RECS data suggest that LAMELs are on average $26 \%$ of the overall electricity use in Midwest homes, both of these homes have higher percentages of LAMEL 
electricity consumption. The Black River Falls home is at $34 \%$ and the Stoughton home is at $41 \%$. As the most efficient lighting and appliances available today have been installed in these homes, much of this electricity consumption falls under MELs. For the Black River Falls home, MELs account for roughly $17 \%$ of total electricity use $(9 \%$ from outlets and $8 \%$ from other sources). For the Stoughton home, MELs are roughly $20 \%$ of the overall electricity use.

As technology continues to inundate our lives, the entertainment center is becoming a larger energy hog. The Black River Falls home had roughly $12.4 \%$ of its LAMELs electricity use or $4.2 \%$ of its overall electricity use attributed to the primary entertainment center.

One component that is likely overlooked in the design process is the well pump and the associated water treatment/softening systems used when city water is not readily available. For the Stoughton home, these components accounted for $12.6 \%$ of the LAMEL electricity use. 


\section{References}

ACCA (1997). Manual RS: Comfort, Air Quality, and Efficiency by Design. Washington DC: Air Conditioning Contractors of America.

CARB (2010) WPPI's GreenMax - Chambers Long Term Monitoring Summary To Date. Accessed 5 December 2011. www.carbswa.com/articles/near\%20zero\%20energy/WPPI\%20GreenMax\%201\%20Monitoring\%20Final \%20Report.pdf. Norwalk, CT: Steven Winter Associates, Inc.

EERE (2011). "Geothermal Heat Pumps." http://www.energysavers.gov/your home/space heating cooling/index.cfm/mytopic=12640. Washington DC: U.S. Department of Energy: Energy Efficiency and Renewable Energy.

EIA (2005). Residential Energy Consumption Survey. Washington, DC: United Stated Energy Information Agency.

Hendron, R.; Engebrecht, C. (2010). Building America House Simulation Protocols. Golden, CO: National Renewable Energy Laboratory.

Hendron, R. (2008). Building America Research Benchmark Definition. Golden, CO: National Renewable Energy Laboratory.

NREL (2011). "NREL Dynamic Maps, GIS Data, and Analysis Tools - Geographic Information System Data Background" http://www.nrel.gov/gis/data analysis background.html. Golden, CO: National Renewable Energy Laboratory.

Pigg, S.; Nevius, M. (2000). Energy and Housing in Wisconsin: A Study of Single-Family Owner-Occupied Homes. Madison, WI: Energy Center of Wisconsin.

Puttagunta, S. (2010). Building America Cold-Climate Prototype Evaluation Report: Shaw Builders/GreenMax 2 Demonstration Home. Norwalk, CT: Steven Winter Associates, Inc.

Roth, K.; Ponoun, R.; Goldstein, F. (2006). U.S. Residential Information Technology Energy Consumption in 2005 and 2010. Cambridge, MA: TIAX, LLC.

WPPI Energy. (2011a). "Black River Falls: Energy Data." www.greenmaxhome.com/projects/ index.php?category id=4462\&subcategory id=6688. Sun Prairie, WI: WPPI Energy.

WPPI Energy. (2011b). "Stoughton: Energy Data." www.greenmaxhome.com/projects/ index.php?category id=4463\&subcategory id=6977. Sun Prairie, WI: WPPI Energy. 


\section{U.S. DEPARTMENT OF Energy Efficiency \& ENERY Renewable Energy}

